\section{Ankara Üniversitesi Eğitim Bilimleri Fakültesi Özel Eğitim Dergisi}

2021, 22(3), 725-747
ARAŞTIRMA

Gönderim Tarihi: 24.08.20

Kabul Tarihi: 27.01.21

Erken Görünüm: 09.02.21

\title{
Özel Yetenekli Öğrencilerin Atık Yönetimi Temalı Doğa Eğitimine Katılma Nedenleri ve Eğitim Sonrası Görüşleri*
}

\author{
Özge Ceylan $(1) 1$
}

Zeynep Aslan (iD)

$\ddot{\mathbf{O} z}$

Giriş: Okul dışı öğrenme ortamlarından olan doğa eğitimi ve bilim kampları, özel yetenekli öğrencilere yönelik zenginleştirilmiş programlar hazırlama firsatı sunar. TÜBíTAK'ın desteklediği bu çalışmada, özel yetenekli öğrenciler için hazırlanan atık yönetimi temalı doğa eğitimine öğrencilerin katılma nedenleri ve sonrasında görüşlerinin incelenmesi amaçlanmıştır.

Yöntem: Nitel araştırma yöntemlerinden durum çalışmasıyla yürütülen araştırmanın çalışma grubu, İstanbul ilindeki BILLSEM'lere kayıtlı 29 özel yetenekli 5. sınıftan 6. sınıfa geçmiş öğrencilerdir. 2019 yılı haziran ayında 5 gün süren projeye dair öğrencilerin görüşleri, içerik analizi kullanılarak incelenmiştir. Veriler, araştırmacılar tarafından hazırlanan başvuru formu ve proje değerlendirme formu ile katılımcı günlükleri aracılığıyla toplanmıştır.

Bulgular: Bulgular öğrencilerin çoğunlukla projeye bilgi edinmek, çeşitli becerilerini geliştirmek ve doğaya olan sevgileri sebebiyle katıldıklarını göstermiş̧ir. Projeye katılırken atıklar ile ilgili bilgi düzeylerinin ise temel ve orta düzey olduğu görülmüştür. Ayrıca projeye yönelik olumlu görüşleri olduğu, atık yönetimi konusunda üst düzey bilgi edindikleri, düşünme becerilerini geliştirdikleri, sosyal ve duygusal doyuma ulaştıkları, çevre farkındalı̆̆ı kazandıkları ortaya çıkmıştır.

Tartışma: Elde edilen bulgular alan yazın ile karşılaştıııldığında, birçok çalışmanın bu çalışmayı desteklediği görülmüştür. Araştırmanın özel yeteneklilerde okul dışı öğretim ve doğa eğitimi uygulamaları ile benzer projelere hazırlık aşamasına katkıda bulunması beklenmektedir. Sonuç olarak, özel yetenekli öğrencilerin istek, ilgi ve merakları doğrultusunda katıldıkları atık yönetimi temalı doğa eğitiminin onların üst düzey bilgi edinmelerine, düşünme becerilerini geliştirmelerine, sosyal ve duygusal olarak doyuma ulaştıklarına, çevreye yönelik farkındalık kazanmalarına katkısı olduğu görülmüştür. Özel yetenekli öğrencilerin çevre eğitimi ihtiyaçlarının yeterli düzeyde karşılanması amacıyla çevre sorunlarını temele alan zenginleştirilmiş ya da farklılaştııılmış etkinlikler, programlar hazırlanabilir.

Anahtar sözcükler: Atık yönetimi, geri dönüşüm, özel yetenekli, doğa eğitimi, TÜBíTAK.

Atıf için: Ceylan, Ö., \& Aslan, Z. (2021). Özel yetenekli öğrencilerin atık yönetimi temalı doğa eğitimine katılma nedenleri ve eğitim sonrası görüşleri. Ankara Üniversitesi Eğitim Bilimleri Fakültesi Özel Eğitim Dergisi, 22(3), 725-747. https://doi.org/10.21565/ozelegitimdergisi.784925

\footnotetext{
*Bu çalışma TÜBİTAK 4004 Doğa Eğitimi ve Bilim Okulu programı altında, 218B148 numarası ile destek alan “Atık Ajanları Dönüşümün Peşinde" projesinden üretilmiştir.

${ }^{1}$ Sorumlu Yazar: Doktora öğrencisi, Y1ldız Teknik Üniversitesi, E-posta: ozgeceylan86@gmail.com, https://orcid.org/00000003-3737-8579

20̈ğretmen, Maltepe Kadir Has Bilim ve Sanat Merkezi, E-posta: zynpasln2525@gmail.com, https://orcid.org/0000-0001$6747-7418$
} 


\section{Giriş}

Atık yönetimi, ülkemizde ilköğretimden yükseköğretime kadar verilen çevre eğitiminin temel konularından biridir. Milli Eğitim Bakanlığı'nın (2018) fen bilimleri dersine ilişkin son programı incelendiğinde çevre eğitimi altında çevre tanımı, kirlilik türleri, atık türleri, geri dönüşüm ve tekrar kullanım, kaynakların verimli kullanımı, yerel ve küresel çevre sorunları konularına değinildiği görülmektedir. Çevre sorunlarıyla mücadele etmek için çeşitli yasal ve teknolojik tedbirler alınsa da bunlar yeterli değildir (Erten, 2003). Çözüm yollarından biri de hiç kuşkusuz doğaya duyarlı bireyler yetiştirmek ve onların olumlu tutum geliştirmelerini sağlamak ile mümkündür. İçinde bulunduğumuz tüketici toplumunun sürekli artan ihtiyaçları sonucu aynı oranda hatta kümülatif olarak çevreye verilen zararın artması sebebiyle, çocuklara verilecek çevre ve çevre sorunları konusundaki eğitim önemli hale getirmektedir (Gülersoy vd., 2020). Çevre eğitiminin en önemli amaçlarından biri, çevre konularına kaygı duyan ve farkındalığa sahip, sorunları çözmek için yeterli bilgisi olan ve bu özelliklerini sürdürülebilir biçimde davranışa döken çevre okuryazarı bireyler yetiştirilmesidir. Bireylerin, bilişsel açıdan çevre okuryazarı olması; duyuşsal açıdan ise çevreye yönelik olumlu tutum ve farkındalık yaratarak, değer yargılarında gelişme sağlayacak disiplinler arası çevre eğitimi ortamları düzenlenmelidir (Ayayadın vd., 2018; Budak, 2008). Çevre eğitimi tüm bireylere verilmelidir ancak bu alanlarda yaşıtlarına göre daha fazla meraka ve problem çözme isteğine sahip olan özel yetenekli bireyler için ileri seviyede çevre eğitimi planlanması daha uygun olacaktır. Sürdürülebilirlik ve çevresel konularla ilgili araştırmalar hem açık uçlu hem de karmaşık olabileceğinden, onlar için ideal çalışma alanlarıdır (Renzulli \& Reis, 2014; Treffinger vd., 2004). O sebeple bu bireylere zenginleştirilmiş, zorlayıcı (challenge), düşünme ve problem çözme becerilerini geliştirici öğrenme ortamları sunmak gerekir. Öğretim ortamını zenginleştirmek, öğrencinin bir konu üzerinde diğerlerinden daha derin ve genişlikte çalışması olarak ifade edilebilir. Zenginleştirme stratejilerini bireysel eğitim, bağımsız çalışma, aşamalı ödevler, araştırma, cumartesi ve okul sonrası programlar, yaz programları, mentörlük, alan gezileri ve çeşitli yaratıcılığı geliştiren projeler şeklinde ifade eden Davis ve diğerleri (2014), zenginleştirme programlarıyla ilgili yapılabilecekleri şu biçimde sıralamıştır:

1. Yaşa göre değil, ihtiyaca göre temel becerilerde maksimum başarı,

2. Mevcut müfredatın ötesinde içerik ve kaynaklar,

3. Çeşitli çalışma alanlarının içinde olma,

4. Derinlemesine çalışmalar dâhil öğrenci tarafından seçilen içerik,

5. Üst düzey içerik karmaşıklığı, teoriler, genellemeler, uygulamalar,

6. Yaratıcı düşünme ve problem çözme becerilerini geliştirme,

7. Üst düzey düşünme becerileri, eleştirel düşünme, kütüphane ve araştırma becerilerini geliştirme,

8. Kendini anlama ve etik gelişim dahil duygusal gelişimi sağlama,

9. Akademik motivasyon, özyönetim ve kariyer hedeflerinin geliştirilmesi,

10. Bilgisayar becerilerinin geliştirilmesi.

Özel yetenekli bireylerin hızlı ve kolay öğrenme, zihinsel süreçlere ve problem çözme becerilerine sahip olma ve etkili çözüm yolları üretme gibi özellikleri vardır (Distin, 2006). Bu bireylerin, bahsettiğimiz özelliklerinden dolayı birçok alanda başarılı olabilmelerini sağlayan potansiyellerinin fark edilmesi ile yüksek benlik kavramına sahip olmaları sağlanmıştır (Hoge \& Renzulli, 1993; McCoach \& Siegle, 2003). Ayrıca birçok sosyal konuda ileri derecede duyarlı olmaları ve yüksek motivasyon ile sorunlara çözüm üretmeleri (Sak, 2012), özel yetenekli bireylere doğanın korunmasına yönelik farkındalık ve bilinç kazandırmanın ne kadar önemli olduğunu göstermiştir. Nacaroğlu ve Bozdağ (2019) çalışmalarında özel yetenekli öğrencilerin çevre sorunlarına ait sonuçlara ve bu sorunların çözümlerine dair algılarının yetersiz olduğunu ifade etmişlerdir. Ayrıca eğitim hayatları süresince bu öğrencilere yeterli çevre eğitiminin verilmediğini de eklemişlerdir. Bu sebeple yetenekli öğrencilere verilecek çevre eğitimi gerekli hale gelmektedir. Yetenekli öğrencilerin çevre sorunlarına dair algıları önemlidir çünkü onlar yerel ve küresel çevre sorunlarına daha fazla duyarlılık göstererek, olası sorunlara çözüm üretmede akranlarına göre aktif rol üstlenirler (Sontay vd., 2014). Küresel sorunlara karşı gösterdikleri hassasiyetin karşılığı olarak (Piechowski, 1997) sahip oldukları üst düzey düşünme, problem çözme becerisi ve ürün üretim becerileri ile çevresel sorunlara karşı farkındalıklarının artırılması gerekli görülmektedir (Mönks vd., 2002). Çevre ile ilgili yapılacak çalışmalar, her yaştan özel yetenekli çocukların eleştirel ve yaratıcı düşünme becerilerini geliştirirken aynı zamanda fen (science), teknoloji (technology), mühendislik (engineering) ve matematik (mathematics) (STEM) alanlarında beceriler geliştirmeleri için fursatlar sunar (Schroth \& Helfer, 2017). Sürdürülebilir çevre eğitimini ortaokul eğitimine entegre etmek, üstün yetenekli çocuklar için ideal olan soyut 
düşüncelerle uğraşmayı gerektirir (Renzulli \& Reis, 2014; Tomlinson vd., 2009; Treffinger vd., 2006). Bu durum, öğrencilerin eleştirel ve yaratıcı düşünme becerilerini geliştirirken, akademik bilgilerini geliştiren etkinliklerine katılmalarını sağlar (National Research Council, 2000; Spellman \& Stoudt, 2013). Bu sebeple sürdürülebilirlik ve çevresel sorunlara odaklanan projeler dil, matematik, sosyal bilgiler, bilim, sanat, müzik ve diğer alanlar dahil olmak üzere müfredatın tüm yönlerine değinebilir (Johnsen \& Kendrick, 2005; Schroth vd., 2011).

Yavuz ve Tortop (2009) özel yetenekli öğrencilerin proje basamağında yapacakları alan gezilerinde birinci elden deneyim kazanmaları ve yaratıcılıklarını artırmaları açısından önemli olduğunu vurgulamaktadır. Üstün yetenekli öğrencilerin çok yönlü gelişimlerinin desteklenmesi okul dışı öğretim uygulamalarının etkili ve sistemli şekilde gerçekleştirilmesine bağlıdır (Freeman, 2012; Pfouts \& Schultz, 2003). Yalnızca sınıf ortamında çevreden uzak bir biçimde teorik olarak öğretilen çevre eğitimi, öğrencilerin doğal çevrelerini yeterli düzeyde tanımamalarına ve çevrelerine bilinçli yaklaşmamalarına sebep olacaktır (Özgel vd., 2018). Oğurlu ve diğerleri (2013) okullarda uygulanan çevre eğitimlerinin, bireylerde çevre duyarlılığı oluşturmada yetersiz kaldığını ifade etmiştir. Öğretmenlerin okul müfredatının yoğunluğu ve eğitim sürelerinin yetersizliği nedenleriyle, öğrencilerinin yaparak ve yaşayarak öğrenmelerini yeterince destekleyemedikleri yapılan araştırmada ifade edilmiştir (Temizöz \& Koca, 2008). Mevcut öğretim programlarında bulunan çevre eğitimi konularının eksiklikleri, öğrencinin aktif öğrenmesi sırasında sürenin yetersiz kalması, derslerde bilginin yoğun şekilde aktarılması karşımıza çevre eğitimlerinin olması gerektiği biçimde verilmemesi problemini çıkarmaktadır. Örneğin Türkiye'de özel yetenekli çocuklara yönelik Bilim ve Sanat Merkezlerinin (BİLSEM) bazılarıın yaz okulu programı hazırladığı bilinmektedir. Amerika'da ise sadece altı özel yetenekli araştırma merkezinde yaklaşık 186.000 özel yetenekli öğrenci, kendileri için hazırlanmış hızlandırma ve zenginleştirme türünde müdahaleler içeren yaz programlarına katılmaktadır (Lee vd., 2008). Bu da bizim ülkemizde yaz kampları, yaz okulları ve okul dışı öğrenme ortamlarının ne derece yetersiz olduğunu göstermektedir.

\section{Doğa Eğitimi Programı}

Özel yeteneklilerde çevre eğitimi ve okul dışı programlar alanında bahsedilen eksiklikleri gidermek amacıyla ülkemizde çeşitli kurumların desteği ile projeler yürütülmektedir. Birçok ülkede öğrencilerin okul dışı eğitim masrafları çeşitli sponsorlar veya devlet kurumları tarafından karşılanarak okul dışı ögretim uygulamaları gerçekleştirilmektedir (Jeronen \& Jeronen, 2012). Türkiye Bilimsel ve Teknolojik Araştırma Kurumunun (TÜBITTAK) nakdi olarak desteklediği bu projeler, özel yetenekli öğrenciler için de zenginleştirilmiş öğrenme ortamlarına katılma firsatı sunar. Alan yazında da (Davis vd., 2014) bahsedildiği gibi özel yetenekli öğrenciler için zenginleştirme yapmak yalnızca içerik bakımından değil, süreç ve ürün boyutunu kapsayan birçok beceriyi ve özelliği geliştirecek biçimde düzenlenmeli ve sunulmalıdır.

Özel yetenekli öğrenciler için yapılan zenginleştirme çalışmaları içerik transferi, müfredat daraltma, bağımsız çalışma, alan gezileri ve okul sonrası programları kapsar. Bu projenin programı ise genel olarak okul sonrası ve okul dışı zenginleştirme türünde oluşturulmuştur. Öncelikle öğrenciler için mevcut müfredatta yer alan atık yönetimi konusu incelenmiştir. Fen bilimleri programında 5. sınıf düzeyine kadar atıklar ve atık yönetimi ile ilgili temel kavramlar verilmektedir. Bu projede ise atık yönetimi ile ilgili temel seviye bilgiler ile başlanmış ve üst sınıf bilgi düzeyinde içerik ile proje hazırlanmıştır. İleri içeriğe yönelik etkinlikler alan gezisi, gözlem, seminer, soru-cevap ve deneyler aracılığı ile çeşitli ortamlarda verilmiştir. Etkinliklerin bir kısmı da yaratıcılık, problem çözme becerisi, araştırma becerisi gibi becerileri merkeze alan etkinlikler olmuştur. Bu etkinlikler ise istasyon tekniği, tartışma, problem çözme yöntemi, STEM aracılığı ile gerçekleştirilmiştir. Bunun yanında programda WEB 2 araçlarının kullanıldığı, teknolojinin atık teması ile entegre edildiği etkinlikler de görülmektedir. Ayrıca drama, grup çalışmaları, yaratıcı tasarım çalışmaları ile öğrencilerin işbirlikli çalışma, çevreye yönelik olumlu tutum gibi sosyal becerileri de geliştirilmeye çalışılmıştır. Projede yer alan etkinliklerden birine ait plan örneği Tablo 1'de görülmektedir. 
Tablo 1

Projede Yer Alan Bir Etkinlik Planı

\begin{tabular}{|c|c|}
\hline Etkinlik ad1 & Gelecek problemleri benim elimde çözüm buluyor \\
\hline Amac1 & $\begin{array}{l}\text { Ögrencilerin var olan veya gelecekte var olabilecek problemlere yönelik ne düşüneceklerine değil, nasıl } \\
\text { düşüneceklerine odaklanan yaratıcı cözüm üretme tekniğini öğrenmeleri ve uygulamaları amaçlanmıştır. }\end{array}$ \\
\hline Konusu & $\begin{array}{l}\text { Paul Torrance tarafından kurulan Torrance Yaratıcılık Merkezi'nde oluşturulan Uluslararası Gelecek } \\
\text { Problemleri Çözme Programı (FPSPI), öğrencilerin eleştirel ve yaratıcı düşünme becerilerini } \\
\text { geliştirmeyi amaçlar. Gelecek problemleri çözme programı müfredat içinde öğrencilerin ilgisini çeken } \\
\text { ve rekabete dayalı yaratıcı problem çözme fırsatları sunar. Eleştirel ve yaratıcı düşünme becerilerini } \\
\text { kullanarak çocukların ve gençlerin pozitif bir gelecek tasarlama ve planlama becerilerini geliştirmeye } \\
\text { dayanan bu etkinlikte, küresel bir çevre sorunu üzerinden geleceğe yönelik yaratıcı problem çözme } \\
\text { tekniğinin basamakları grup çalışması ile uygulamalı olarak anlatılacaktır. }\end{array}$ \\
\hline $\begin{array}{l}\text { Kullanılacak } \\
\text { malzeme }\end{array}$ & $\begin{array}{l}\text { Geçmiş tarihli gazete sayfaları } \\
\text { Bant } \\
\text { Renkli karton kâğıtlar } \\
\text { A4 kâğıdı } \\
\text { Renkli kalemler } \\
\text { Atık malzemeler } \\
\text { Bilgisayar ve yansıtıcı } \\
\text { Ses sistemi }\end{array}$ \\
\hline $\begin{array}{l}\text { Uygulanacak } \\
\text { yöntem }\end{array}$ & Grup çalı̧̧ması \\
\hline Süre & $60^{\prime}+60^{\prime}$ \\
\hline $\begin{array}{l}\text { Uygulama } \\
\text { planı }\end{array}$ & $\begin{array}{l}\text { Giriş } \\
\text { Öğrencilere atık gazeteler gösterilerek bu malzeme ile en yüksek kuleyi nasıl yaparsınız? sorusu sorulur. } \\
\text { Gelişme } \\
\text { Öğrenciler } 5 \text { kişilik } 6 \text { gruba ayrılır. } \\
\text { Her bir gruba gazete sayfaları ve yapıştırma bandı verilir. } \\
\text { Kendilerinden verilen süre içinde en yüksek ve en uzun süre ayakta kalabilecek bir kule yapmaları } \\
\text { istenir. } \\
\text { En yüksek kuleden daha yüksek ve daha uzun sureli dayanabilecek bir kule yapımı için daha ne } \\
\text { yapılabilir? sorusu eğitmen tarafından sorulacak ve yaratıcı düşünme becerisinin sınırının olmayacağı } \\
\text { üzerinde durulacaktır. } \\
\text { Ne düşüneceklerini mi yoksa nasıl düşüneceklerini mi bilmenin önemi üzerine tartışmaları için iki gruba } \\
\text { ayrılan öğrencilere münazara yaptırılır. } \\
\text { Gelecek problemleri çözme program tekniğinin amacı, bileşenleri ve yararları anlatılır. } \\
6 \text { basamaklı yaratıcı problem çözme tekniği anlatılır. } \\
5 \text { kişilik } 6 \text { gruptan olası küresel çevre problemleri oluşturmaları istenir ve ortak kararla bir problem } \\
\text { seçilir. } \\
\text { Sonuç } \\
\text { Her bir grubun seçilen probleme yönelik gelecek problemleri çözme program tekniğinin basamaklarına } \\
\text { dayanarak çözüm bulmaları ve çözümlerini istedikleri teknikle sunmaları istenir. } \\
\text { Büyük grup oylaması ile en yaratıcı çözüm önerisi seçilir. }\end{array}$ \\
\hline
\end{tabular}

2019 yılı haziran ayında öğrencilerle beş gün boyunca toplam 40 saat süren 26 etkinlikten oluşan bir uygulama yapılmıştır. Öğrencilerin ana etkinlik merkezi olan Kartal BİLSEM dışında eğitim aldığ yerler; Ömerli İçme Suyu Arıtma Tesisi, Paşaköy İleri Biyolojik Atık Su Tesisi, Eyüp İSTAÇ atık depolama, dönüşüm, kompost tesisleri, Gebze Teknik Üniversitesi Çevre Mühendisliği laboratuvarları, Pera Müzesi’dir. Bu alanlarda yapılacak etkinliklerde zenginleştirme çalışması yapılırken, proje çıktısı olarak öğrencilerin belirlenen temaya dair akranlarından ile düzeyde akademik bilgi edinmeleri, üst düzey düşünme becerilerini geliştirmeleri ve yaratıcı çözümler üretmeleri hedeflenmiştir.

Bu çalışmanın amacı da TÜBITTAK desteği ile özel yetenekli öğrencilere yönelik gerçekleştirilen “Atık Ajanları Dönüşümün Peşinde” isimli 4004 Doğa Eğitimi ve Bilim Okulu Projesi’ne öğrencilerin katılım nedeni ve uygulama sonucunda projeye yönelik görüşlerini ortaya koymaktır. Bu çalışmanın da bundan sonra yapılacak proje ve araştırmalara, öğrencilerin ihtiyaçları doğrultusunda hazırlık yapılması noktasında 1şık tutması beklenmektedir. 
Daha önce farklı katılımcılar veya özel yetenekli öğrencilere yönelik yapılan projelerin değerlendirme çalışmaları (Ayaydın vd., 2018; Demirhan, 2018; Hırça, 2013; Kınık-Topalsan vd., 2019; Öztürk-Akar \& Ayvaz, 2018; Öztürk vd., 2020; Su, 2019) mevcuttur. Ülkemizde özel yeteneklilerde okul dışı öğrenme ortamlarının ve çevre eğitimi araştırmalarının, son yıllarda üzerinde durulan bir konu olduğu söylenebilir. Öğrencilerin bu tür okul dışı ortamlardan elde ettiği kazanımların ortaya konması onların bilişsel, sosyal ve psiko-motor gelişimleri hakkında bilgi sahibi olmalarına firsat sunabilir. Ayrıca araştırmanın doğa eğitimi ve bilim okulu projelerinin beklenti ve sonuçlarına, okul dışı öğrenme ortamları ve yaz kampları kazanımlarına, atık yönetimi ve çevre eğitimi alanına katkıda bulunması beklenmektedir. Bu çalışmanın örneklem özelliği, atık yönetimi teması, uygulama alanları, etkinlikleri birlikte ele alındığında araştırmanın özgün olduğu düşünülmektedir. Verilen bilgiler doğrultusunda araştırmanın soruları aşağıdaki gibidir:

1. Özel yetenekli öğrencilerin atık yönetimi temalı doğa eğitimine katılım nedenleri nelerdir?

2. Özel yetenekli öğrencilerin atık yönetimi temalı doğa eğitimi uygulamalarına yönelik düşünceleri nedir?

\section{Yöntem}

\section{Araştırma Deseni}

Özel yetenekli öğrencilerin atık yönetimi temalı doğa eğitimi projesine katılım nedenleri ve uygulama sonucunda projeye yönelik görüşlerini ortaya koymak amacıyla yapılan bu çalışma nitel araştırma yöntemlerinden durum çalışması kullanılarak yürütülmüşsür. Durum çalışması, nasıl ve niçin sorularını temele alarak, gerçek hayatın ya da güncel ortam içerisindeki bir durumun incelenmesine (Yin, 2009); kontrol altına alınamayan olgu ya da olayların ayrıntılı bir biçimde irdelenmesine (Yıldırım \& Şimşek, 2016); bireylerin deneyimlerine dayanarak kendilerini nasıl algıladıkları, duyguları ve bunların altında yatan sebeplerin ortaya konmasina (Gillham, 2000) imkân tanıyan nitel araştırma yöntemidir. Bu araştırmada uygulanan doğa eğitimi programına yönelik bir değerlendirme söz konusu olduğundan bütüncül tek durum deseni kullanılmıştır.

\section{Çalışma Grubu}

Araştırmanın çalışma grubu amaçlı örnekleme yöntemlerinden ölçüt örnekleme yöntemi ile seçilmiştir. Örneklem seçiminde kullanılan ölçütler; İstanbul'da yer alan BİLSEM'lerden birine kayıtlı olmak, 5. sınıftan 6. sınıfa geçmiş olmak, daha önce bir 4004 projesine katılmamış olmak ve programın konusu olan atık yönetimine ilgi duymaktır. Online başvuru formu ile okullarına projeden bir ay önce duyuru yapılmış, ölçütleri sağlayan ve gönüllü olduğu kabul edilen başvurular arasından seçilmiştir. Katılımcılar 15 kız 14 erkek toplam 29 özel yetenekli öğrenciden oluşmaktadır. Katılımcıların demografik yapısı Tablo 2'de görülmektedir.

Tablo 2

Katılımcıların Demografik Yapısı

\begin{tabular}{llc}
\hline \multicolumn{1}{c}{ Değişken } & \multicolumn{1}{c}{ Kategori } & $f$ \\
\hline \multirow{2}{*}{ Cinsiyet } & Kiz & 15 \\
& Erkek & 14 \\
Okul türü & Devlet okulu & 19 \\
& Özel okul & 10 \\
& İlköğretim & 1 \\
Anne eğitim durumu & Lise & 4 \\
& Lisans & 14 \\
& Lisansüstü & 10 \\
Baba eğitim durumu & İlköğretim & 1 \\
& Lise & 3 \\
& Lisans & 23 \\
\hline
\end{tabular}

\section{Araştırmacının Rolü ve Yeterliği}

Araştırmacı, verilerini topladığı projenin yürütücüsüdür ve projenin yürütüldüğü kurumda öğretmen olarak görev yapmaktadır. Doktora öğrencisi olan araştırmacı fen eğitimi, çevre eğitimi, atık yönetimi ve özel yetenekliler ile ilgili çeşitli yayınlara sahiptir ve doktora tez konusu özel yetenekliler ile ilgili fen müfredat tasarımı üzerinedir. Daha önce benzer projelerde katılımcı, eğitmen, yürütücü gibi görevlerde bulunmuştur. Proje 
programının içeriğini öğrencilerin özelliklerini göz önünde bulundurarak hazırlamış, proje yürütme esnasında aynı zamanda gözlemci rolünde olmuştur.

\section{Veri Toplama Araçları}

Araştırmada öğrencilerin projeye katılım nedenlerini belirlemek amacıyla başvuru formu, uygulamaya dair düşüncelerini belirlemek amacıyla katılımcı günlüğü ve proje değerlendirme formu veri toplama aracı olarak kullanılmıştır.

\section{Proje Başvuru Formu}

Araştırmacı/proje yürütücüsü tarafından geliştirilen başvuru formunda kişisel bilgiler bölümünün yanında “Doğa ĕgitimine neden katılmak istediğinizi ve bu eğitimden beklentilerinizi yazınız?” sorusu ile “Atık yönetimi ile ilgili ne biliyorsunuz?" sorusu yer almıştır. Sorular hazırlanırken benzer projelerde sorulmuş sorular ve TÜBİTAK'ın kriterleri göz önünde bulundurulmuştur. Projede bulunan alan uzmanından görüş alınmış ve son hali verilmiştir. Bu iki sorudan elde edilen cevaplar analiz edilerek, araştırmanın birinci sorusuna cevap aranmıştır.

\section{Katılımcı Günlü̆ğ̈̈}

Projeye dâhil olan öğrencilere projenin etkinlikleri başlamadan önce günlükler dağıtılmıştır. Öğrencilerden bu günlükleri yapılan etkinlikler, proje ortamı, sosyal ilişkiler, eğitimciler, kazanımları gibi duygu ve düşüncelerini ayrıntılı olarak her gün yazmaları istenmiştir. Proje sonunda öğrencilerden günlükler değerlendirme yapmak amacıyla toplanmıştır. Öğrenci günlüklerinden elde edilen bilgiler bilgisayar ortamına aktarıldıktan sonra kendilerine geri verilmiştir.

\section{Proje Değerlendirme Formu}

Öğrencilerin projenin uygulama haftasına dair düşüncelerini belirlemek amacıyla 10 açık uçlu soru içeren form, araştırmacı tarafından geliştirilmiş ve proje uzmanları tarafından kontrol edilip son hali verilmiştir. Form sorular1;

1. Proje ile ilgili genel düşüncelerin nelerdir?

2. Projede yapılan etkinlikleri çevrendeki insanlarla paylaştın mı? Kimlerle paylaştın?

3. Proje süresince verilen ödevleri ne kadar yaptın?

4. Senin bu projeye katılman, evinizde burada ele alınan konularla ilgili değişiklikler/gelişmeler olmasına ne kadar katkı sağladı?

5. Bu projenin en çok beğendiğin yanları nelerdi?

6. Bu projenin sevmediğin veya değiştirilmesini isteyeceğin yanları nelerdi?

7. Proje sayesinde atık yönetimi ile ilgili öğrendiğin yeni kavramlar var mı? Varsa nelerdir?

8. Atık yönetimi ile ilgili proje geliştirmek istesen ne gibi çözüm önerilerin olur?

9. Projenin sana katkısı oldu mu? Olduysa örnek vererek açıklayınız (bilgi, sosyal ilişkiler, duygusal gelişim vb.)

10. Proje beklentilerini karşıladı mı? Hedeflediğin kazanımların ne kadarını elde ettin? şeklindedir.

\section{Verilerin Toplanması ve Analizi}

Başvuru aşamasında kullanılan başvuru formu ile katılımcılar seçilmiş, etkinlik programı beş gün uygulanmıştır. Bu süre boyunca öğrencilere katılımcı günlüğü yazdırılmıştır. Beşinci günün sonunda proje değerlendirme formu verilmiş ve öğrencilerden doldurmaları istenmiştir.

Başvuru formu, günlük ve proje değerlendirme formu için puanlama yapılmamıştır. Verilerin analizi içerik analizi yöntemi ile yapılmıştır. Toplanan veriler iki farklı araştırmacı tarafından ayrı ayrı kodlanmıştır. Ardından tema ve kategoriler oluşturulmuş, düzenleme yapılmıştır. İki araştırmacının tema ve kategorileri karşılaştırılmış ve benzer olanlar doğrudan alınmış olmayanlar üzerinde fikir birliğine varılarak tekrar oluşturulmuştur. Sonunda her kod için frekans $(f)$ değeri bulunmuştur. Araştırmanın güvenirliğini sağlamak amacıyla iki araştırmacı arasında kategoriler Miles ve Huberman'ın (1994) formülü (Güvenirlik = Görüş birliği / Görüş ayrılığ1 + Görüş birliği) ile hesaplanmıştır. Sonucunda çalışmanın araştırmacılar arası güvenirliği \%86 bulunmuştur. Bu değer de araştırmacılar arası güvenilirliğin sağlandığını göstermektedir.

Araştırma niteliğinin sağlanması amacıyla: etik tutum olarak kullanılan veri toplama araçları için önceden ilgili ilçe milli eğitim müdürlüğünden izin alınmış; katılımcılara ve velilerine, uygulama öncesinde bilgi verilmiş 
ve yalnızca gönüllü öğrencilerin katılımları sağlanmış, projeden çekilmek isteyen öğrenciler (bir öğrenci projenin ikinci günü çekilmiştir) zorlanmamış; katılımcılar $\mathrm{O}_{1}, \ddot{\mathrm{O}}_{2}, \ddot{\mathrm{O}}_{3} \ldots \mathrm{O}_{29}$ şeklinde kodlanmış; araştırmadan elde edilen veriler oynanmadan doğrudan aktarılmış; veri toplama, araştırmacı çeşitliliği yapılmış; araştırma yöntemi açık ve anlaşılır biçimde anlatılmıştır. Araştırma 2018 yılında planlandığ 1 ve 2019 yılında veri toplandığı için etik kurul izni alınmamış, araştırmanın yapılacağı ilçenin milli eğitim müdürlüğünden yasal izin belgesi alınmıştır.

\section{Bulgular}

Araştırmanın birinci sorusu "Özel yetenekli öğrenciler atık yönetimi temalı doğa eğitimine katılım nedenleri nelerdir?" şeklindedir. Bu soruya yönelik öğrencilerin başvuru formunda yer alan sorulara verdikleri cevaplardan elde edilen bulgular Tablo 3'te görülmektedir.

\section{Tablo 3}

Özel Yetenekli Öğrencilerin Atık Yönetimi Temalı Doğa Eğitimine Katılma Nedenleri

\begin{tabular}{cll}
\hline Tema & \multicolumn{1}{c}{ Kategori } & \multicolumn{1}{c}{ Kod } \\
\hline Bilgi & Bilgi edinme & Derinlemesine bilgi (10), Temel bilgi (8) \\
& Bilimsel süreç becerisi & Problem çözme (2), Fark etme (2), Araştırma (1), Gözlem (1) \\
& Düşünme becerisi & Yaratıcı düşünme (4), Meta-bilişsel düşünme (öz kapasite) (3) \\
Beceri & Mühendislik tasarım becerisi & Ürün üretmek (3), Proje üretmek (1) \\
& Öğrenme becerileri & Alan gezileri (2), Alan uzmanı (1) \\
& & Doğa sevgisi (9), Farkındalık (8), Duyarlılık (3), İlgi (2), Merak (2), \\
\multirow{2}{*}{ Tutum } & Duyuşsal boyut & Gönüllülük (1), Sorumluluk (1), Eğlenme (1) \\
& & Çevreyi koruma (6), Kişileri bilinçlendirmek (5), Girişimcilik (1), Akran \\
& Davranış boyutu & iletişimi (1), Kaynakları verimli kullanma (1), Kirliliğe engel olma (1)
\end{tabular}

Tablo 3’te görüldüğü gibi özel yetenekli öğrencilerin atık yönetimi temalı doğa eğitime katılma nedenleri bilgi, beceri ve tutum olmak üzere üç tema ve onlara bağlı yedi kategori ile 26 kod altında toplanmıştır.

Öğrencilerin katılma nedenlerinden bir kısmı "bilgi” teması altında toplanmış, bilgi edinme kategorisine bağlı temel bilgi $(f=8)$ ve derinlemesine bilgi $(f=10)$ kodları ile iki tür bilgiden söz etmişlerdir. Ayrıca öğrencilere atık yönetimi ile ilgili ne bildikleri sorulmuş ve öğrencilerin cevapları incelendiğinde açıklamaları temel düzey ( $f$ $=14)$, orta düzey $(f=10)$ ve iyi düzeyde $(f=5)$ olduğu görülmüştür.

Bilgi edinme kategorisinde derinlemesine bilgi koduna ait olarak $\ddot{O}_{3}$ isimli öğrenci:

"Atıkların imhası ve saklanması hakkında detaylı bilgi edinebilmek için." ifadesini, $\ddot{O}_{5}$ isimli öğrenci “...Ve atık degerlendirme konusunda detaylı bilgilenmesini saglayıp ilerisi için merak ve farkındalık oluşturabilmek...” ifadesini ve $\ddot{O}_{20}$ isimli öğrenci “...Babam Prof. Dr. Kriton Curi'nin öğrencilerindenmiş. Öğrenciyken çöplüklerde metan gazı ölçümü yaptıklarını ve çöpleri ayrıştırarak tarttıklarını anlatmıştı. Bu da benim çok ilgimi çekmişti. Ben de bu konuda ayrıntılı bilgi edinmek isterim... " ifadesini kullanmışlar ve projeye katılma nedenleri arasında derinlemesine bilgi edinmek olduğunu belirtmişlerdir. Temel bilgi koduna ait $\mathrm{Ö}_{18}$ isimli öğrenci "Doğa eğitimine katılma nedenim doğa ve atık yönetimi ile ilgili bilgim az bu yüzden en baştan bilgi almak ve bu konuda daha çok çalışma yapmak ayrıca çevremdeki insanları bilgilendirmek..." ve Ö$_{14}$ isimli öğrenci "Atıkların toplanması, geçirdiği yolculuk, sonunda bize geri dönüşş şekli... en başından itibaren öğrenmek ve bilgi almak istiyorum..." şeklinde düşüncelerini belirtmişler ve projeye katılım nedeni olarak atık yönetimi konusunda temel bilgi edinmeyi göstermişlerdir.

Öğrencilerin katılma nedenlerinin bir kısmı da "beceri" teması altında toplanmıştır. Bu tema bilimsel süreç becerisi $(f=5)$, düşünme becerisi $(f=7)$, mühendislik tasarım becerisi $(f=4)$ ve öğrenme becerileri $(f=3)$ kategorilerine sahiptir.

Bilimsel süreç becerisi kategorisine ait öğrenci cevaplarında, fark etme kodunda $\ddot{O}_{1}$ isimli öğrenci “...Çevremdeki doğa problemlerinin farkındayım ve gözlemliyorum..." ifadesini kullanarak atık yönetimi ve çevre sorunlarını hakkında farkında olduğunu söylemiştir. Problem çözme kodunda ise Ö$_{17}$ isimli öğrenci “Ülkemizdeki atık geri dönüşüm sorunlarına çözüm üretmek istiyorum.” diyerek atık yönetimi problemini çözmek istediğini belirtmiştir. Araştırma kodunda $\ddot{O}_{24}$ isimli öğrenci "Çevre sorunlarını araştırmayı ve doğayı seviyorum..." ifadesini kullanmış ve çevre sorunlarını araştırmak amacıyla projeye katıldığını dile getirmiştir. 
Düşünme becerisi kategorisine ait öğrenci cevaplarında Ö$_{29}$ isimli öğrenci yaratıcı düşünme kodunda “...Gelecekte bu alanda gerçekleştirilecek çözümlere yaratııı fikirlerle katkıda bulunmak istiyorum..." ifadesini kullanarak çevre sorunlarını yaratıcı bir biçimde çözmeyi amaçlamıştır. Meta-bilişsel düşünme kodunda $\mathrm{O}_{2}$ isimli öğrenci "Bu konuda neler yapabileceğimin farkına varmak istiyorum. Bununla ilgili bu faaliyette kendimi geliştirebileceğimi düşünüyorum.” demiş ve öz kapasitesini arttırmayı amaçlamıştır. Öğrencilerin bir kısmı proje aracılığı ile bir takım düşünme becerilerini geliştirmek için katılım göstermek istemişlerdir.

Mühendislik tasarım becerisi kategorisine ait öğrenci cevaplarında ürün üretmek kodunda Ög isimli ögrenci “...Atıklarla ilgili doğaya faydalı makineler yapmak istiyorum.” ve Ö 4 isimli öğrenci “...Atıkları dönüştürebilecek robot yapmak istiyorum. Böyle bir fikrim var umarım yapabilirim..." diyerek projeye ürün üretmek amacıyla katıldıklarını dile getirmişlerdir. Proje üretmek koduna $\mathrm{O}_{27}$ isimli öğrenci “...Geri dönüşüm projelerimi hayata geçirmek için.” ifadesini kullanmış, atık sorununa proje üreterek çözüm getireceğini belirtmiş̧ir. Öğrenciler projeye katıldıklarında bazı tasarım becerilerini işe koşacaklarını ifade etmişlerdir.

Öğrenme becerileri kategorisine ait öğrenci cevaplarında alan gezisi kodunda $\ddot{O}_{25}$ isimli öğrenci "Değişik yerler görmeyi çok seviyorum. Nasıl çalışır belgesellerini çok severim ve izlerim. Atık tesislerini görmek ve nasıl çalıştıklarını öğrenmek istiyorum..." ifadesini kullanarak atık yönetimi ile ilgili tesislerini görmek amacıyla projeye katılmak istediği belirtmiştir. Alan uzmanı kodunda $\mathrm{O}_{8}$ isimli öğrenci “...bu konularda uzman kişilerden fikir almak ve fikir sunmak yaşadığımız çevre için neler yapabiliriz bunu öğrenmek için katılmak istiyorum.” İfadesini kullanmış ve doğa eğitimine katılım amacını, alan uzmanından eğitim almak ile ilişkilendirmiştir.

Öğrencilerin katılma nedenleri son olarak "tutum" teması altında toplanmıştır. Tutum temasında duyuşsal boyut $(f=27)$ ve davranış boyutu $(f=15)$ olmak üzere iki kategori oluşturulmuştur.

Duyuşsal boyut kategorisi altında doğa sevgisi koduna örnek olarak Ö${ }_{11}$ isimli öğrenci "Doğayı çok sevdiğim için onu korumanın etkin yöntemlerini öğrenmek istiyorum." demiş ve katılım nedeni olarak doğa sevgisini göstermiştir. Gönüllülük kodunda $\ddot{O}_{1}$ isimli öğrenci “...Doğayı korumak için gönüllüyüm. Bu yüzden projede olmak istiyorum" ifadesini kullanmış ve doğayı korumaya gönüllü olduğunu belirtmiştir. Merak koduna $\ddot{O}_{21}$ isimli öğrenci “...evlerimizden çöp kamyonlarıly toplanan çöplerin nasıl doğaya zarar vermeden yok edildiğini merak ediyorum." diyerek atıkların geçirdiği yolculuğa dair merakını dile getirmiştir. Duyarlılık ve farkındalık kodunda $\ddot{O}_{10}$ isim öğrenci "Çevreye duyarlıyım ve bu alandaki bilgilerimi ve farkındalı̆̆ımı artırmak istiyorum" cümlesi ile çevreye dair duyarlı ve farkındalığı olduğunu ortaya koymuştur. İlgi ve sorumluluk kodunda Ö$_{10}$ isimli öğrenci "Doğaya ve çevreye karşı ilgim ve sorumluluğum olduğunu düşünüyorum biz çocukların ileride yetişkin olup is sahalarında görev aldığımızda bu bilinçle yetişmiş kişiler olursak daha çevreci kararlar alabiliriz." ifadesini kullanarak katılım amacını sahip olduğu sorumluluk ve ilgi ile ilişkilendirmiştir. Eğlenme koduna $\mathrm{O}_{13}$ isimli öğrenci "Hem öğrenmek hem de eğlenceli zaman geçirmek istiyorum." diyerek katılım amacını eğlenceli zaman geçirmek olarak belirtmiştir.

Davranış boyutu kategorisi altında akran iletişimi koduna örnek olarak $\ddot{O}_{5}$ isimli öğrenci “....benim gibi düşünen arkadaşlarla tanışıp sosyalleşmek istiyorum...” diyerek yeni arkadaşlar edinmeyi amaçladığını söylemiş̧ir. Kişileri bilinçlendirmek kodunda $\mathrm{O}_{12}$ isimli öğrenci "Doğa ile uyumlu yaşamayı hayatıma sokmayı ve bilinçlenerek, başkalarını da bilinçlendirmek." demiş ve öncelikle kendini bilinçlendirip bunu sosyal hayatına yaymayı amaçlamıştır. Girişimcilik kodunda $\mathrm{O}_{24}$ isimli öğrenci "Çünkü ben girişimciyim ve atık yönetiminde bunu kullanacağım" ifadesinde bulunmuş ve sahip olduğu kişilik özelliğini bu alanda kullanmak istediğini söylemiştir. Çevreyi korumak kodunda Ö$_{6}$ isimli öğrenci "Doğanın korunması için mümkün olduğunca az atık çıkarmak ve atıkların geri dönüşümünü sağlamak için birşeyler yapmak istiyorum.” diyerek çevreyi korunması adına yapılabilecek faaliyetleri öğrenmek amacıyla katılmak istemiştir. Kaynakları verimli kullanma kodunda $\mathrm{O}_{29}$ isimli öğrenci “...bana yeterli gelmiyor, doğal kaynakların kullanımı ve atık yönetimi ile ilgili daha fazla şey öğrenmek istiyorum.” İfadesini kullanarak enerji verimliliği kavramından söz etmiştir. Kirliliğe engel olma kodunda $\mathrm{Ö}_{10}$ isimli öğrenci "buradan öğreneceğim bilgiler ile çevre kirliliğine engel olmak istiyorum.” diyerek katılım amacını belirtmiştir.

Araştırmanın ikinci sorusu "Özel yetenekli öğrencilerin atık yönetimi temalı doğa eğitimi uygulamalarına yönelik düşünceleri nedir?” şeklindedir. Öğrencilerin proje değerlendirme formuna verdikleri cevaplar ve katılımcı günlükleri incelendiğinde elde edilen verilere ait bulgular Tablo 4 'te görülmektedir. 
Tablo 4

Özel Yetenekli Öğrencilerin Atık Yönetimi Temalı Doğa Eğitimi Uygulamalarına Yönelik Düşünceleri

\begin{tabular}{|c|c|c|}
\hline Tema & Kategori & Kod \\
\hline $\begin{array}{l}\text { Etkinliklere } \\
\text { yönelik görüş }\end{array}$ & $\begin{array}{l}\text { Tür } \\
\text { Say1 }\end{array}$ & $\begin{array}{l}\text { Gezi (18), Deney (15), Tümü (12), Drama (10), Problem çözme (7), Proje (5) } \\
\text { Az sayıda gezi (5), Çok sayıda test(12) }\end{array}$ \\
\hline $\begin{array}{l}\text { Etkinliklere } \\
\text { yönelik görüş }\end{array}$ & Özellik & $\begin{array}{l}\text { Eğlenceli (23), Bilgilendirici (20), Bilinçlendirici (18), Faydalı (16), İlgi çekici (11), } \\
\text { Geliştirici (7), Sıkıcı (2), Yorucu (2), Alakasız (1) }\end{array}$ \\
\hline $\begin{array}{l}\text { Sürece yönelik } \\
\text { görüş }\end{array}$ & $\begin{array}{l}\text { Duygu } \\
\text { Paylaşım } \\
\text { Süre } \\
\text { Hizmetler }\end{array}$ & $\begin{array}{l}\text { Sevgi (29), Mutluluk verici (13), Eğlenceli (12), Heyecanlı (9) } \\
\text { Aile (23), Arkadaş (8) } \\
\text { Kısa süreli (4) } \\
\text { Uygulama yerleri (9), Yemekler (5), Ücretsiz olması (2) }\end{array}$ \\
\hline $\begin{array}{l}\text { Temaya yönelik } \\
\text { görüş }\end{array}$ & $\begin{array}{l}\text { Atık yönetimi } \\
\text { Çevre }\end{array}$ & $\begin{array}{l}\text { Bilgi edinme (17), Bilinç kazanma (14), Farkındalık oluşma (14), Eve katkı (11), } \\
\text { Uygulamaya dökme (8), Ülkeye katkı (3) } \\
\text { Bilinç kazanma (26), Koruma (21), Çözüm Üretme (8) }\end{array}$ \\
\hline $\begin{array}{l}\text { Kazanımlara } \\
\text { yönelik görüş }\end{array}$ & $\begin{array}{l}\text { Yeni bilgi } \\
\text { Duyuşsal kazanım } \\
\text { Sosyal kazanım }\end{array}$ & $\begin{array}{l}\text { Geri dönüşüm (20), Geri kazanım (13), Atık tesisi (11), Arıtma (9), Atık türleri (8), } \\
\text { Tekrar kullanım (5), Çevre laboratuvarı (2), Mesleki bilgi (2), Atık bertarafı (1) } \\
\text { Duyarlılık (22), Aileyi bilinçlendirme (17), Arkadaşları bilinçlendirme (8) } \\
\text { Yeni arkadaş edinme (7), Uzman ile tanışma (3) }\end{array}$ \\
\hline
\end{tabular}

Atık yönetimi temalı beş günlük doğa eğitimine katılan 29 özel yetenekli öğrencinin görüşlerini tespit etmek amacıyla günlükler ve proje değerlendirme formları incelendiğinde Tablo 4'te yer alan tema, kategori ve kodlar bulunmuştur. Dört tema, 13 kategori ve onlara bağl1 kodlar elde edilmiştir.

“Etkinliklere yönelik görüş” teması tür $(f=67)$, süre $(f=13)$, sayı $(f=17)$ ve özellik $(f=98)$ olmak üzere dört kategoriye sahiptir. Bu tema, projede yapılan etkinlikler hakkında öğrencilerin düşüncelerini ele alır. Tür kategorisi, programda yer alan etkinlik türlerine yönelik yapılan yorumları; süre kategorisi, etkinliklerin süreleri ile ilgili yapılan yorumları; sayı kategorisi etkinliklerin sayılarına ait yorumları ve özellik kategorisi etkinliklerin genel özellikleri hakkında yapılan yorumları içermektedir.

Katılımcıların etkinliklere yönelik görüș teması tür, süre, sayı ve özellik kategorilerine örnek olarak bir öğrenci “...Projede çok yer gördük. En çok gezi yapılan günleri sevdim eğlenceliydi. Bana çok katkısı olduğunu düşünüyorum. Atıklar konusunda bilinçlendim ailemide bilinçlendirdim onlarda çok memnun kaldı. İyi ki katılmışım..." (Ö $8,22.06 .2019)$ ifadesinde bulunmuş ve genel olarak gezi etkinliklerini sevdiğini, eğlenceli ve faydalı olduğunu belirtmiştir. Ö${ }_{13}$ isimli öğrenci de "Bugün üniversiteye gittik. Uzmanlar laboratuvarda deneyler yaptırdı. Çok ilgimi çekti. Ayrıca profesör bize kimyasal atıkları, günlük hayatımızdaki kimyasalları anlattı. Eve gelince anneme öğrendiklerimi anlattım. O da bilinçlendi bu sayede. Gözlüklü önlüklü fotoğraflar çekildik, arkadaşlarım eğlenceli pozlar verdi. Keşke daha çok gezi olsa.” (21.06.2019) cümlesini yazarak etkinliklerin özelliklerinden ve olumlu deneyimlerinden söz etmişlerdir. Bir başka öğrenci "Dün çok sıkıldım bugün gitmek istemedim ama annem git dedi. Fakat bugün çok güzel geçti, etkinlikler faydalıydı. Bence testler çok sıkıcı ve çok fazla. Onlar olmasa daha iyi olur." (Ö̈ $\left.{ }_{21}, 19.06 .2019\right)$ şeklinde ifade kullanmış ve projede yapılan ölçme etkinliklerine dair olumsuz düşüncelerini dile getirmiştir. Ö gündü. Drama yaparak yeni arkadaşlarla tanıştım. Çok eğlenceliydi hatta öğretmenlerde katıldı. Yeni yeni bilgiler öğrendik faydalıydı..." $\left(\ddot{O}_{18}, 18.06 .2019\right)$ diyerek dile getirmiştir. Yine başka bir öğrenci projede yer alan bazı etkinlikleri anlayamadığını ve sıkıldığını belirtmiş ve "projenin genelde tüm etkinlikleri güzeldi, bazıları atıklarla alakasızdı anlayamadım neden yaptık. Testler bölümünde çok sıkıldım...” (Ö $24,22.06 .2019)$ demiştir. Projenin etkinlik günlerinin süresinin kısa olmasını belirten bir öğrenci de düşüncelerini "Bugün sadece okuldaydık gezi yoktu belki diğer günler olur. Çok yoruldum çünkü bence biraz geç saatte bitiyor. Gün sayısı fazla olabilirdi etkinlikler diğer günlere dağıtılabilirdi. Problem çözme etkinliği yaptık çok eğlenceliydi masalara çıkıp en uzun kuleyi yapmaya çalıştık ama biz kazanamadık :..." (Ö̈ $\left.\ddot{O}_{3}, 18.06 .2019\right)$ biçiminde belirtmiştir.

“Sürece yönelik görüş" teması duygu $(f=63)$, paylaşım $(f=31)$, süre $(f=4)$ ve hizmetler $(f=16)$ olmak üzere dört kategoriye sahiptir. Bu tema projenin genel olarak yapısı, yürütülmesi gibi boyutları ele alır. Duygu kategorisi, proje geneline yönelik hissedilen duygular1; paylaşım kategorisi projeyi kimlerle paylaştıkları; süre kategorisi projenin genel süresine ait düşünceleri ve hizmetler kategorisi projeden alınan hizmetler hakkında yapılan yorumları içermektedir. 
Katılımcıların sürece yönelik görüş teması duygu, paylaşım, süre ve hizmetler kategorilerine ait verdikleri cevaplara örnek olarak $\ddot{O}_{4}$ isimli öğrenci "Projeyi çok sevdim katıldığım için çok mutluyum. Çok yer gördük çok bilgiler öğrendik. Hepsi eğlenceliydi..." $\left(\ddot{O}_{4}, 22.06 .2019\right)$ diyerek duygularından söz etmiş̧tir. Yine $\ddot{O}_{12}$ isimli öğrenci de "...Burada olmaktan çok mutluyum. Babamla her gün etkinlikleri konuştuk onlarda yeni yeni bilgiler öğrendi. Yaz tatilimi verimli geçirmek iyi oldu arkadaşlarımada anlatacağım burayı. Kısaca çok sevdim çok teşekkür ederim." (Ö $\left.{ }_{12}, 22.06 .2019\right)$ duygularından bahsetmiş ve çevresi ile öğrendiklerini paylaştı̆ııı ifade etmiştir. $\ddot{O}_{19}$ isimli öğrenci duygularına ek olarak projenin süresine yönelik öneride bulunmuş ve “....atık ajanlarını çok sevdim. Katılırken çok heyecanlıydım yeni bilgiler öğrenmek ailemle paylaşmak onlarıda mutlu etti. Süresi biraz daha uzun olabilirdi..." (Ö $\left.{ }_{19}, 22.06 .2019\right)$ demiştir. $\ddot{O}_{27}$ isimli öğrenci projeyi sevdiğini ve ekonomik bakımdan ona firsatlar sunduğunu "Ben en çok yemekleri sevdim hemde bedavaydı herşey. Okulda gezilere katılamıyordum benim için güzel firsat oldu. İyiki katılmışım herkeze çok teşekkürler." (Ö $\left.{ }_{27}, 22.06 .2019\right)$ cümlesi ile ortaya koymuştur. Bir öğrenci de projenin süresinin daha uzun olması gerektiğini "Bugün projenin son günüydü bittiği için üzüldüm çünkü çok sevmiştim her sabah erken kalkmak olsada mutluydum. Keşke biraz daha gelebilsek $\otimes . . . "\left(\ddot{O}_{17}, 22.06 .2019\right)$ şeklinde ifade etmiştir. $\ddot{O}_{10}$ öğrenci de "Projeye yönelik düşüncem genelde olumlu. Yemekler güzeldi etkinlikler güzeldi bazıları heyecan vericiydi. Tekrarı olursa katılabilirim..." (Ö $\ddot{10}_{10}$ 22.06.2019) diyerek hizmetlere yönelik düşüncelerinden ve yemeklerden bahsetmiştir.

"Temaya yönelik görüş" teması atık yönetimi $(f=67)$ ve çevre $(f=55)$ olmak üzere iki kategoriye sahiptir. Bu tema, projenin teması olan atık yönetimi hakkında öğrencilerin düşüncelerini ortaya koyar. Attk yönetimi kategorisi programda atık yönetimi başlığı altında öğrencilerin düşüncelerini bir araya toplarken; çevre kategorisi, çevre ile ilgili yapılan yorumları içermektedir.

Katılımcıların temaya yönelik görüş temasına ait verdikleri cevaplara örnek olarak $\ddot{O}_{1}$ isimli öğrenci “...Bugün İSTAÇ gezisinde kimyasal atıklar tıbbi atıklar gibi atık türlerini öğrendim. Çevreyi koruma bilinci kazandım. Annemle ne yapabiliriz diye konuştuk artık evimizde atıkları ayırmaya daha çok dikkat ediyoruz..." $\left(\ddot{O}_{1}, 20.06 .2019\right)$ diyerek atık yönetimine dair öğrendiği bilgilerden ve çevre koruma bilinci kazandığından söz etmiştir. Ö 16 isimli öğrenci de çevre koduna örnek olacak biçimde "Bugün yaptığımız etkinlikte bana çevre sorunlarına çözüm üretme şansı verdi. Fikirlerimi büyük heyecanla öğretmenler ile paylaştım, araştırma yaptım umarım birgün bu sorunları çözebilirim..." (Ö $\left.{ }_{16}, 19.06 .2019\right)$ cümlesini kurmuştur. Ö ${ }_{26}$ isimli öğrenci atık yönetimi temasında "...proje sayesinde ben ve ailem bilinçlendik. Bu tür projelerin çoğalmasını herkesin katılmasını isterim. Evimizde atıklarla ilgili bazı kurallar oluşturduk. Herkes yaparsa ülkeye büyük katkısı olur..." $\left(\ddot{O}_{26}, 22.06 .2019\right)$ ifadesini kullanmıştır. Yine başka bir öğrenci de atık yönetimi ve çevre temasında "...atık yönetimini öğrenerek hem çevreyi korumuş hem tasarruf yapmış oluruz. Bu yüzden evde atıklarımızı farklı poşetlerde toplamaya karar verdik..." (Ö $\left.{ }_{11}, 21.06 .2019\right)$ demiş ve eğitim sonunda evde atıklara karşı aldıkları önlemlerden söz etmiştir. Ö${ }_{24}$ isimli öğrenci ise atık yönetimi koduna "Bugün yaptı̆̆ımız etkinlikte atıkların hayvanları nasıl etkilediğini gördük. $\mathrm{Bu}$ konu üstüne biraz düşündüm ve bu sorunu nasıl çözebiliriz diye

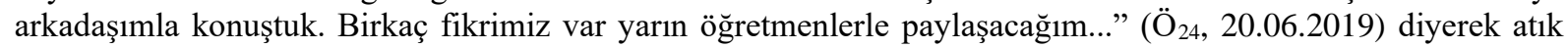
yönetiminin hayvanlar üzerindeki etkisine dikkat çekmiştir.

"Kazanımlara yönelik görüş” teması yeni bilgi $(f=71)$, duyuşsal kazanım $(f=47)$, sosyal kazanım $(f=$ 10) olmak üzere üç kategoriye sahiptir. Bu tema öğrencilerin proje süresince edindikleri kazanımları içermektedir. Yeni bilgi kategorisi, projeden öğrencilerin öğrendiği bilgi türlerini; duyuşsal kazanım kategorisi, öğrencilerin projeden edindiği tutum, davranış duygu gibi duyuşsal kazanımları; sosyal kazanım kategorisi, öğrencilerin proje süresince sosyal becerileri hakkında yorumlarını içermektedir.

Katılımcıların projeden elde ettikleri kazanımlara yönelik görüş temasında $\ddot{O}_{22}$ isimli öğrenci "Bugün İSKİ gezimiz çok eğlenceliydi burada çevre mühendisi bir ablayla tanıştım ne iş yaptığını öğrendim. Örneğin su arıtma tesisi nasıl çalışır atıklar nasıl geri dönüştürülür bu bilgileride öğrendim çok faydalıydı. Artık doğaya daha farklı bakacağım dikkatli davranacağım..." (Ö $\left.{ }_{7}, 22.06 .2019\right)$ demiştir. Öğrencinin ifadesinde öğrendiği bilgiler ile yeni bilgi kategorisine, yeni insanlarla tanışması sosyal kazanım kategorisine, eğlenmesi ve farkındalı̆̆ artması ise duyuşsal kazanım kategorisine örnek ifadeler olarak ortaya çıkmışır. Ö${ }_{14}$ isimli öğrenci “.... gezide otobüste yanıma tanımadığım bi kız oturdu önce istememiştim ama sonra çok iyi anlaştı facebookta ekledim yeni arkadaşım oldu. Tüm gezide beraberdik. Gezilerin nasıl olduğunu soracak olursan günlük, geri dönüşüm aşamalarını ögrendim. Atıklar nasıl bertaraf edilir öğrendim. Kardeşime anlattım oda bilinçlensin istiyorum. Artık çevreye çöp atılsın istemiyorum herkez bu duyarlılığı kazanmalı.” $\left(\ddot{O}_{14}, 21.06 .2019\right)$ demiştir. Öğrencinin ifadesinde yeni arkadaş edindiğini ve kardeşi ile bilgisini paylaştı̆ıını söylerek sosyal kazanım kategorisine, edindiği bilgilerden bahsederek yeni bilgi kategorisine ve duyarlılıktan söz ederek de duyuşsal kazanım kategorisine ait örnekler yer almıştır. ${ }_{29}$ isimli öğrencinin “....̧evre mühendisliğinin laboratuvarları çok güzeldi 
çok sevdim deney yapmak tam bana göre. Tekstil atık suyunu boyasından ayırdık çok ilginçti. Üniversitedeki öğretmenler çok bilgilendirdiler. Arkadaşıma bahsettim keşke oda gelebilseydi daha çok eğlenirdik..." $\left(\ddot{O}_{29}\right.$, 21.06.2019) ifadesinde yeni bilgi ve sosyal kazanım temalarından örnek cümleler görülmektedir. Son olarak $\mathrm{O}_{15}$ isimli öğrenci de "Bugün geri dönüşüm, geri kazanım, tekrar kullanım kelimelerinin aynı anlama gelmediğini öğrendim. Ben hepsi aynı sanıyordum ama değilmiş. Pet şişeden yaptığım kalemlik tekrar kullanıma giriyormuş. Ne kadar çok bilgi varmış bazen hepsini aklımda tutamıyorum..." $\left(\ddot{O}_{15}, 19.06 .2019\right)$ diyerek yeni bilgi kategorisine ait ifadelerde bulunmuştur.

\section{Tartışma}

Özel yetenekli öğrencilerin atık yönetimi temalı doğa eğitimine katılma nedenlerini ve eğitim sonrası görüşlerini ortaya koymayı amaçlayan bu çalışma, TÜBİTAK tarafindan desteklenen bilim ve toplum programlarından olan 4004 kodlu "Atık Ajanları Dönüşümün Peşinde" isimli projeden elde edilen verilerin bir kısmı kullanılarak yapılmışıtır.

Projeye katılımcı seçilirken neden katıldıkları sorulmuş ve elde edilen kodlar bilgi, beceri ve tutum olmak üzere üç kategori altında toplanmıştır. Projenin genel amaçları; katılımcıların bilgi seviyelerini arttırmak, atıklar konusunda bilinçli hale getirmek, eğlenerek öğrenmelerini sağlamak, atık yönetimi ve geri dönüşüm alanlarını yerinde incelemek, kendileri gibi özel yetenekli akranları ile araştırma, sorgulama ve atık sorunlarına yaratıcı çözümler üretmeye yönelik davranışlar kazandırmak olarak belirlenmiştir. Öğrenciler çoğunlukla atık yönetimi konusunda bilgi edinme amacıyla katıldıklarını ifade etmişlerdir. Ayrıca doğayı çok sevdiğini, atıklar konusunda farkındalığı arttırmak ve çevreyi korumak istediğini söyleyen öğrenciler çoğunluktadır. Renzulli ve Reis (2014) özel yetenekli öğrencilerin doğaya karşı özel ilgileri ve tutkuyla bağlı olduklarını ifade etmişlerdir. Beceri kategorisi incelendiğinde çevre sorunlarını yaratıcı bir biçimde çözmek ve ürün üretmek, öz-kapasitesini geliştirmek isteyen öğrenciler yer almaktadır. Bu durumda öğrencilerin başvuru amaçları ile projenin genel amaçlarının örtüştüğü söylenebilir. Bu tür programlarda katılımcıların hedefi ile proje hedefi örtüşüyorsa, elde edilen kazanımlar daha anlamlı ve kalıcı olacaktır. Çünkü öğrenme gerçekleşirken bilişsel ve duyuşsal hazırbulunuşluk önemlidir. Öztürk-Akar ve Ayvaz (2018) özel yetenekli öğrencilerin benzer bir projeye katılma nedeni olarak konuya ilgi duymaları, potansiyellerini geliştirmek istedikleri, yeni bilgiler ve yeni arkadaşlar edinmek istediklerini çalışmalarında ortaya koymuşlardır. Bu araştırmada ise farklı olarak öğrencilerden yalnızca biri katılım nedeni olarak, kendi gibi akranları ile iletişim kurmak istediğini ifade etmiştir. Bu bulguya benzer olarak Şahin ve diğerleri (2019) özel yetenekli lise öğrencileri ile yaptıkları okul dışı bilim eğitimine 35 öğrenciden yalnızca iki öğrencinin iletişim kurmak ve işbirliği yapmak için katıldığını ifade etmiş̧lerdir. Özel yetenekli öğrencilerin sosyal duygusal olarak sorun yaşadıkları bilinmektedir (Sak, 2012). Bu çalışmadan çıkan bulgu ile öğrencilerin sosyal olarak yalnız olma hislerini yansıttıkları söylenebilir. Bu tür organizasyonlarda sosyal becerileri geliştirmeye dayalı etkinlik sayısı arttırılabilir ve temel amaçlardan biri haline getirilebilir.

Projenin değerlendirilmesi amacıyla incelenen katılımcı günlükleri ve proje değerlendirme formlarından elde edilen bulgulara göre öğrencilerin cevapları etkinliklere, sürece, temaya ve kazanımlara göre kategorize edilmiştir. Etkinlikleri değerlendiren öğrenciler, tür olarak en fazla gezilerden, deneylerden ve genel olarak tümünden memnun olduklarını ifade etmişlerdir. Özel yetenekliler ile ilgili yapılan okul dışı eğitim ortamları çalı̧̧alarında Ayaydın ve diğerleri (2018) öğrencilerin eğlenerek öğrendiklerini ve bilgilerin kalıcı olduğunu; Tortop (2012) öğrencilerin çevreye yönelik tutumlarında belirgin gelişme ve enerji konusunda bilgilerinin arttı̆̆̆ını; Çavuş ve diğerleri (2013), öğrencilerin çevre bilinci kazanmalarında okul dışı öğrenme ortamlarının önemli bir yeri olduğunu ve okul dışında yapılan etkinliklerin sayısının artırılması gerektiğini belirtmişlerdir. Diğer bir bulguda öğrenciler ölçme değerlendirme etkinliklerinde kullanılan testleri sayıca fazla ve süre olarak uzun bulduklarını ifade etmişlerdir. Ayrıca öğrencilerin testleri yaparken sıkıldığı da gözlenmiştir. Bu durumun kaynağı olarak son yıllarda BİLSEM'ler aracıllğıyla özel yetenekli öğrencilere yönelik yapılan bilimsel araştırmalardaki artış ve öğrencilerin sık sık testlere maruz kalması yorumu yapilabilir. Projelerde ölçme değerlendirme faaliyetlerinin önemli olduğu bilinmekle beraber öğrencileri sıkmamak adına onların seviye ve ihtiyaçları göz önünde bulundurulması önerilebilir. Yine öğrenciler etkinliklerin çoğunlukla eğlenceli, bilgilendirici ve bilinçlendirici olduğu yönünde görüş bildirmiştir. Benzer birçok çalışmada (Altan vd., 2019; Hırça, 2013; Öztürk vd., 2020; Öztürk-Akar \& Ayvaz, 2018; Su, 2019) bahsedilen bulgulara rastlanmıştır. Olumlu görüşlerin yanında sıkıcı, yorucu ve alakasız şeklinde ifadelere rastlanmıştır. Bu yorumlar sayıca az olmakla birlikte öğrencilerin bazı etkinliklerden sıkıldığı; gün içerisinde sabah saatlerinde başlayıp akşam saatlerinde sona eren ve yoğun bir program olduğu için yoruldukları; bazı etkinlikleri de atık yönetimi ile ilişkilendiremedikleri görülmüş̧ür. Benzer çalışmalarda da özel yetenekli öğrencilerden bazılarının çevre eğitimlerini sıkıcı, yoğun ve zor olarak tanımlayabildikleri belirtilmektedir (Ayaydın vd., 2018; Öztürk-Akar \& Ayvaz, 2018). Öğrencilerin ilgi 
ve yeteneklerinin farklı olduğu düşünülerek her yöntemin dikkatlerini çekemeyeceği akla gelmektedir. Bu noktada sıkılan öğrenciler için farklı öğretimsel müdahaleler yapılabilir. Programın yoğunluğunu azaltmak için de gün sayısı arttırılabilir ya da etkinlik sayısı azaltılabilir. Warber ve diğerleri (2015) okul dışı öğrenme ortamları ya da kamplar konusunda genel kanının, kamp sürelerinin uzun olması ile kalıcı sonuçlar elde edildiği yönünde olduğunu ifade etmişlerdir. Projeye yönelik genel yorumlara dair olumlu bulgular ise çoğunlukla projenin sevildiği, aile ile proje hakkında paylaşım yapıldığı, uygulama alanlarının sevildiği ve yemekler hakkındaki memnuniyettir. Projeyi aile ya da arkadaşlar ile paylaşma durumu, atık yönetimi ile ilgili bilgilerin yaygınlaştırılması, TÜBİTAK'ın tanıtımı ve olumlu düşünce geliştirmeye katkı sağlayabilir. Olumsuz yorum ya da öneri olarak ifade edilebilecek bulgu ise projenin gün sayısının daha fazla olmasıdır. Ayrıca projenin ücretsiz olması öğrenciler tarafından dile getirilen olumlu bir özelliktir. Öğrencileri çevre eğitimi konusunda eğitmek önemli olmakla birlikte, bazı kaynaklarda birçok çocuğun bu dersi alma firsatı olmadığı ifade edilmiştir (Spellman \& Stoudt, 2013). Bu tür projelerin öğrenciler arasında firsat eşitliği yarattığı, özellikle dezavantajlı bireylere (sosyo-ekonomik durum, özel eğitim öğrencisi olması, etkinliklere ulaşma zorluğu vb.) yönelik olunca proje değerinin arttığı bilinmektedir. Bu sebeple projeye çoğunlukla devlet okulunda öğrenim gören öğrenci $(f=19)$ seçilmiştir.

Atık yönetimi kategorisinde öğrencilerden gelen cevaplar doğrultusunda tema ile ilgili olan kavramlar belirlenmiş̧ir. Genel olarak atık yönetimi ve çevre teması hakkında birçok bilgi, duygu, tutum, davranış içeren deneyimler yaşandığı ifade edilmiştir. Bilgi edinme, bilinç kazanma, farkındalık, ev ve ülke ekonomisine katkı gibi sonuçlar ile projenin amaçlarına ulaşıldığı görülmektedir. Sürdürülebilirlik ve çevresel kaygılar ile ilgili konuların araştırılması özel yetenekli öğrencilerin sorunları tespit etmesine, araştırma soruları geliştirmelerine, verileri toplamalarına ve analiz etmelerine, olası çözümler geliştirmelerine ve bu bilgileri başkalarına yaymalarına izin verir (Schroth \& Helfer, 2017). Öğrencilerin projeden edindiği kazanımlar arasında yeni bilgi kazanımı yer almaktadır. Atık yönetimi ve çevre eğitimine dair akranlarından ileri düzeyde birçok kavram öğrendikleri, farkındalıklarını arttırıp atık sorununa yönelik çözüm üretme aşamasına geldikleri görülmüştür. Yapılan benzer çalışmalarda her yaştan bireyin doğa kampı, bilim ya da yaz okullarının çevre bilinci ve çevresel tutumlarına büyük ölçüde katkı sağladığı (Akbaşlı, 2018; Keleş vd., 2010), bilime ve bilimsel çalışmalara karşı ilgilerini artırdığı (Akay, 2013), çevreye olan duyarlılıklarını ve çevre kirliliğine yönelik farkındalık düzeylerini arttırdığı belirtilmektedir (Avcı vd., 2015; Feyzioğlu vd., 2012; Ugulu, 2019).

$\mathrm{Bu}$ çalışmanın sonucu olarak, özel yetenekli öğrencilerin istek, ilgi ve merakları doğrultusunda katıldıkları atık yönetimi temalı doğa eğitiminin onların üst düzey bilgi edinmelerine, düşünme becerini geliştirmelerine, sosyal ve duygusal olarak doyuma ulaşmalarına etkisi olduğu söylenebilir. Ayrıca çevreye yönelik farkındalık ve bilinç kazanmalarına da katkısı olduğu görülmüştür. Özel yetenekli öğrencilerin sahip oldukları yetenekleri göz önünde bulundurarak onları geleceğin önemli çevre sorunlarından biri olan atık yönetimi konusunda eğitmenin önemli olduğu, potansiyellerini bu sorunları çözme yönünde kullanabilecekleri düşünülmektedir. Küçük yaşlardan itibaren verilen doğa eğitimlerinin onların çevre sorunların fark etme ve duyarlılık kazanmaları ile başlayan ilk adımları olacağı söylenebilir.

\section{Araştırmanın Sinırlılığı ve Öneriler}

Yapılan araştırma İstanbul ili, 29 özel yetenekli öğrenci, atık yönetimi teması, 5 gün ve 40 saat süren 26 etkinlik ve kullanılan veri toplama araçları ile sınırlıdır. Bu doğrultuda sonraki çalışmalara dair şu öneriler verilebilir:

1. Atık yönetiminin öncelikle eğitim programlarında ayrıntılı olarak yer alması ve okullarda çeşitli geri dönüşüm kampanyaları düzenlenmesi önerilebilir.

2. Proje süreleri bir haftadan daha uzun süreli olabilir. Bu projede yer alan öğrencilerin isteği de aynı yöndedir.

3. Gelecekte özel yetenekli öğrenciler de dahil tüm öğrencilere yönelik hazırlanması planlanan projeler üst düzey düşünme becerini, 21. yy. becerilerini, problem çözme becerilerini geliştirmeye yönelik olmalıdır.

4. Benzer temada bir projenin erken farkındalık ve duyarlılık kazandırmak amacıyla, daha küçük yaşta olan özel yetenekli öğrencilere uygulaması yapılabilir.

5. Eğitimlere öğrencilerin ilgileri doğrultusunda başvurduğu düşünüldüğünde, yalnızca çevre eğitimi ya da atık yönetimi temasında değil birçok farklı alandan spesifik konularda proje önerileri hazırlanabilir. 
6. Özel yetenekli öğrencilerin çevre eğitimi ihtiyaçlarının yeterli düzeyde karşılanması amacıyla öğretmenler çevre sorunlarını temele alan zenginleştirilmiş ya da farklılaştııılmış etkinlikler, programlar hazırlayabilir.

7. Okul dışı öğretim yöntemlerine yıllık planlarda daha fazla yer verilmelidir.

\section{Yazarların Katkı Düzeyleri}

Özge CEYLAN destek alınan projenin yürütücüsüdür. Aynı zamanda araştırmanın konusunu belirleyen, veri toplayan, veri analizi yapan ve raporlamanın büyük çoğunluğu yapan araştırmacıdır. Zeynep ASLAN, projede eğitmendir. Araştırmanın veri toplama, veri analizi yapma yardımı ve raporun bir bölümünü yazma görevini gerçekleştirmiştir.

\section{Teşekkür}

Araştırmamıza mali kaynaklık eden TÜBİTAK ve projenin gerçekleştirilmesinde ayni desteklerini esirgemeyen Kartal Bilim ve Sanat Merkezine teşekkürlerimizi sunarız. 


\section{Kaynaklar}

Akay, C. (2013). Ortaokul öğrencilerinin TÜBITTAK “4004 yapıyorum öğreniyorum yaz bilim okulu” projesi sonrası bilim kavramına yönelik görüşleri [The opinions of the secondary school students towards science concept following "TUBITAK 4004 learning by doing summer science school"]. Mersin Üniversitesi Eğitim Fakültesi Dergisi, 9(2), 326-338. https://dergipark.org.tr/tr/pub/mersinefd/issue/17383/181626

Akbaşl1, S. (2018). The evaluation of nature education training. International Online Journal of Education and Teaching (IOJET), 5(2), 295-311. http://iojet.org/index.php/IOJET/article/view/385/236

Altan, E. B., Üçüncüoğlu, I., \& Öztürk, N. (2019). Preparation of out-of-school learning environment based on science, technology, engineering, and mathematics education and investigating its effects. Science Education International, 30(2), 138-148. https://doi.org/10.33828/sei.v30.i2.7

Avcı, E., Özenir, Ö. S., Kurt, M., \& Atik, S. (2015). TÜBITTAK 4004 doğa eğitimi ve bilim okulları kapsamında ortaokul öğrencilerine yönelik gerçekleştirilen "Bizim Deniz Akdeniz" projesinin değerlendirilmesi [Assessment of "Our sea is Mediterranean" project planned for secondary school students financed by TUBITAK under 4004 nature and science schools program]. Amasya Üniversitesi Eğitim Fakültesi Dergisi, 4(2), 312-333. https://dergipark.org.tr/en/download/article-file/234050

Ayayadın, Y., Acar-Şeşen, B., Usta-Gezer, S., \& Camcı-Erdoğan, S. (2018). Environmental awareness and sensitivity of the gifted students "science and art explorers in the nature". Bartin Üniversitesi Ë̆itim Fakültesi Dergisi, 7(2), 507-536. https://doi.org/10.14686/buefad.379723

Budak, B. (2008). Illköğretim kurumlarında çevre eğitiminin yeri ve uygulama çalışmaları [The status of environmental education in primary school and application studies] (Tez Numarası: 215970) [Yüksek lisans tezi, Ege Üniversitesi]. Yükseköğretim Kurulu Ulusal Tez Merkezi.

Çavuş, R., Topsakal, Ü. U., \& Öztuna-Kaplan, A. (2013). İnformal öğrenme ortamlarının çevre bilinci kazandırmasına ilişkin öğretmen görüşleri: Kocaeli bilgi evleri örneği [Teachers views' on awareness of environmental acquiring in informal learning environments: The sample of Kocaeli science houses]. Pegem Eğitim ve Ögrretim Dergisi, 3(1), 15-26. http://www.pegem.net/dosyalar/dokuman/1379072013042911303-makale-2.pdf

Davis, G. A., Rimm, S. B., \& Siegle, D. (2014). Education of the gifted and talented (6th ed.). Pearson Education Limited.

Demirhan, E. (2018). Opinions of gifted students and prospective teachers on nature education program based on mentoring approach, Inonu University Journal of the Faculty of Education, 19(3), 175-188. https://doi.org/10.17679/inuefd.483536

Distin, K. (Ed.). (2006). Gifted children: A guide for parents and professionals. Jessica Kingsley Publishers.

Erten, S. (2003). 5. sınıf öğrencilerinde "çöplerin azaltılması" bilincinin kazandırılmasına yönelik bir öğretim modeli [By the study of a teaching model on development of awareness on "garbage reduction" for the fifth class students]. Hacettepe University Journal of Education, 25, 94-103. https://dergipark.org.tr/tr/pub/hunefd/issue/7813/102572

Feyzioğlu, B., Özenoğlu-Kiremit, H., Öztürk-Samur, A., \& Aladağ, E. (2012). YİBO’lar doğal ortamda bilimsel düşünüyor [YIBO's are thinking scientifically in natural environtment]. Eğitim ve Öğretim Araşstırmaları Dergisi, 1(4), 65-74. http://dx.doi.org/10.7827/TurkishStudies.44074

Freeman, M. (2012). Kurt Hahn: Inspirational, visionary, outdoor and experiential educator. History of Education: Journal of the History of Education Society, 41(4), 563-565, https://doi.org/10.1080/0046760X.2012.680924

Gillham, B. (2000). Case study research methods. Bloomsbury Publishing.

Gülersoy, A. E., Dülger, İ., Dursun, E., Ay, D., \& Duyal, D. (2020). Nasıl bir çevre eğitimi? Çağdaş yaklaşımlar çerçevesinde bazı öneriler [What kind of environmental education? Some suggestions in the context of $\begin{array}{lllll}\text { contemporary } \quad \text { approaches]. } & \text { Turkish } & \text { Studies, } & \text { 15(5), } & \text { 2357-2398. }\end{array}$ http://dx.doi.org/10.7827/TurkishStudies.44074 
Hırça, N. (2013). Gifted students' summer science camp experiences. Journal of Gifted Education Research, 1(1), 22-30. http://www.acarindex.com/dosyalar/makale/acarindex-1423937373.pdf

Hoge, R. D., \& Renzulli, J. S. (1993). Exploring the link between giftedness and self-concept. Review of Educational Research, 63(4), 449-465. https://doi.org/10.3102/00346543063004449

Jeronen, E., \& Jeronen, J. (2012). Outdoor education in Finnish schools and universities. https://tr.scribd.com/document/159479238/Finland-1

Keleş, Ö., Uzun, N., \& Uzun, F. V. (2010). Öğretmen adaylarının çevre bilinci, çevresel tutum, düşünce ve davranışlarının doğa eğitimi projesine bağlı değişimi ve kalıcılı̆̆ının değerlendirilmesi [The change of teacher candidates' environmental consciousness, atitude, thought and behaviors with nature training project and the assessment of its]. Electronic Journal of Social Sciences, 9(32), 384-401. https://dergipark.org.tr/tr/pub/esosder/issue/6146/82520

Kınık-Topalsan, A., Türk, Z., \& Güler, G. (2019). Korunmaya muhtaç çocuklara yönelik gerçekleştirilen "Doğada bilim yapıyorum!" TÜBITAK 4004 projesinin değerlendirilmesi [Assessment of the project "Doing science in nature!" carried out for children in need of protection financed by TUBITAK under 4004]. Itobiad: Journal of the Human \& Social Science Researches, 8(1), 581-607. https://doi.org/10.15869/itobiad.488344

Johnsen, S. K., \& Kendrick, J. (Eds.). (2005). Science education for gifted learners. Prufrock Press.

Lee, S. Y., Matthews, M. S., \& Olszewski-Kubilius, P. (2008). A national picture of talent search and talent search educational programs. Gifted Child Quarterly, 52(1), 55-69. https://doi.org/10.1177/0016986207311152

McCoach, D. B., \& Siegle, D. (2003). The structure and function of academic self-concept in gifted and general education students. Roeper Review, 25(2), 61-65. https://doi.org/10.1080/02783190309554200

Milli Eğitim Bakanlığı [Ministry of National Education]. (2018). Fen bilimleri dersi öğretim programı (İlkokul ve ortaokul 3, 4, 5, 6, 7, 8. siniflar) [Science course curriculum (Primary and secondary school 3, 4, 5, 6, 7, 8. grades)]. https://ttkb.meb.gov.tr/www/ogretim-programlari/icerik/72

Miles, M. B., \& Huberman, A. M. (1994). Qualitative data analysis: An expanded source book (2nd ed.). Sage.

Mönks, F. J., Heller, K. A., \& Passow, H. A. (2002). The study of giftedness: Reflections on where weare and where we are going. In K. A. Heller, F. J. Mönks, R. J. Sternberg, \& R. F. Subotnik (Eds.), International handbook of giftedness and talent (2nd ed., pp. 839-863). Elsevier.

Nacaroğlu, O., \& Bozdağ, T. (2020). Özel yetenekli öğrencilerin çevre sorunlarına yönelik algılarının kelime ilişkilendirme testi kullanılarak incelenmesi [An investigation into the perceptions of gifted students on environmental problems by using word association test]. Gazi Üniversitesi Gazi Eğitim Fakültesi Dergisi, 40(2), 385-409. http://www.dergipark.org.tr/tr/pub/gefad/issue/56462/573864

National Research Council. (2000). Inquiry and the National Science Education Standards: A guide for teaching and learning. National Academies Press.

Oğurlu, I., Alkan, H., Unal, Y., Ersin, M. O., \& Bayrak, H. (2013, 10-13 Haziran). Çevre ve doğa eğitimlerinin coğrafya eğitimine katkları: IDE projeleri örneği [Contributions of environment and nature training to geography education: IDE projects case study] [Sözlü bildiri]. 3. Uluslararası Coğrafya Sempozyumu, Antalya, Türkiye.

Özgel, Z. T., Aydoğdu, M., \& Yıldırım, E. G. (2018). Doğa kampı destekli çevre eğitiminin çevre sorunlarına yönelik farkındalık ve tutuma etkisi [Impact of nature camp-assisted environmental education on awareness and attitude towards environmental problems]. Ihlara Eğitim Araştırmaları Dergisi, 3(2), 90106. https://dergipark.org.tr/en/download/article-file/495322

Öztürk-Akar, E., \& Ayvaz, Ü. (2018). Üstün yetenekli çocuklar neden bir bilim okulu projesine katılmak ister? [Why do gifted students wants to participate in a science school project?]. Milli Eğitim Dergisi, 47(1), 333-342. https://dergipark.org.tr/tr/pub/milliegitim/issue/40518/481766 
Öztürk, N, Bozkurt-Altan, E., \& Tan, S. (2020). Ortaokul öğrencilerinin "geleceğe hazırlanıyorum: Problemlere çözüm arıyorum" projesinin kendilerine katkılarına yönelik değerlendirmelerinin incelenmesi [Investigation of the middle school students' evaluation on the self-contribution of the project named "preparing for future: Looking for solutions"]. Milli Eğitim Dergisi, 49(225), 153-179. https://dergipark.org.tr/tr/pub/milliegitim/issue/52526/690649

Pfouts, B. R., \& Schultz, R. A. (2003). The benefits of outdoor learning centers for young gifted learners. Gifted Child Today, 26(1), 56-63. https://doi.org/10.4219/gct-2003-91

Piechowski, M. M. (1997). Emotional giftedness: The measure of intrapersonal intelligence. In N. Colangelo \& G. A. Davis (Eds.), Handbook of gifted education (2nd ed., pp. 366-381). Allyn \& Bacon.

Renzulli, J. S., \& Reis, S. M. (2014). The school-wide enrichment model: A how-to guide for talent development (3rd ed.). Prufrock Press.

Sak, U. (2012). Üstün zekalılar: Özellikleri tanılanmaları eğitimleri [Gifted and talented: Characteristics, identification, education]. Vize Yayınc1lı.

Schroth, S. T., \& Helfer, J. A. (2017). Gifted \& Green: Sustainability/environmental science investigations that promote gifted children's learning. Gifted Child Today, 40(1), 14-28. https://doi.org/10.1177/1076217516675903

Schroth, S. T., Helfer, J. A., Beck, D. L., \& Swanson, B. L. (2011). Planning differentiated instruction and assessing results: Teaching to assure each learner's success. Kendall/Hunt.

Sontay, G., Gökdere, M., \& Usta, E. (2014). Üstün yetenekli öğrencilerle akranlarının çevresel davranışlarının karşılaştırmalı incelenmesi [A comparative investigation of environmental behaviors of gifted students and their peers]. Türk Üstün Zekâa ve Ĕgitim Dergisi, 4(2), 90-106. https://app.trdizin.gov.tr/makale/TWpNek9EVTBOQT09

Su, Ş. (2019). TÜBİTAK 4004 kapsamında yürütülen “Özel yetenekliler arkeoloji ile tarihe dokunuyor” projesinin degerlendirilmesi [The evaluation of the project "The gifted students touch the history with archeology" project carried out within the scope of TUBITAK 4004]. Informal Ortamlarda Araştirmalar Dergisi, 4(2), 117-143. https://dergipark.org.tr/en/pub/jrinen/issue/51520/582440

Spellman, F. R., \& Stoudt, M. (2013). Environmental science: Principles and practices. Scarecrow Press.

Şahin, E., Kabasakal, V., \& Çelebi, Ö. (2019, 23-27 Ekim). Informal öğrenme ortamlarında gerçekleştirilen bilim eğitimlerine yönelik özel yetenekli ögrencilerin görüssleri [The views of gifted students on science education conducted in informal learning environments] [Sözlü Bildiri]. 2. Uluslararası Temel Eğitim Kongresi, Muğla Sitkı Koçman Üniversitesi, Muğla, Türkiye.

Temizöz, Y., \& Koca, S. A. Ö. (2008). Matematik öğretmenlerinin kullandıkları öğretim yöntemleri ve buluş yoluyla öğrenme yaklaşımı konusundaki görüşleri [The instructional methods that mathematics teachers use and their perceptions on the discovery approach]. Eğitim ve Bilim, 33(149), 89-103. http://egitimvebilim.ted.org.tr/index.php/EB/article/view/643

Tomlinson, C. A., Kaplan, S. N., Renzulli, J. S., Purcell, J. H., Leppien, J. H., Burns, D. E., Strickland, C. A., \& Imbeau, M. B. (2009). The parallel curriculum: A design to develop learner potential and challenge advanced learners (2nd ed.). Corwin Press.

Tortop, H. S. (2012). Üstün yetenekli öğrencilerle yenilenebilir enerji kaynakları ile ilgili anlamlı alan gezisi [The meaningful field trip of gifted students about renewable energy resources]. Abant Izzet Baysal Üniversitesi Bolu Eğitim Fakültesi Dergisi, 12(1), 181-196. https://dergipark.org.tr/en/download/article$\underline{\text { file/16823 }}$

Treffinger, D. J., Isaksen, S., \& Stead-Doval, B. (2006). Creative problem solving: An introduction (4th ed.). Prufrock Press.

Treffinger, D. J., Nassab, C. A., Schoonover, P. F., Selby, E. C., Shepardson, C. A., Wittig, C. V., \& Young, G. C. (2004). Thinking with standards: Preparing for the future (Middle ed.). Prufrock Press. 
Ugulu, İ. (2019). Efficacy of recycling education integrated with ecology course prepared within the context of enrichment among gifted students. International Journal of Educational Sciences, 26(1-3), 49-58. https://www.doi.org/10.31901/24566322.2019/26.1-3.1086

Warber, S. L., DeHudy, A. A., Bialko, M. F., Marselle, M. R., \& Irvine, K. N. (2015). Addressing "nature-deficit disorder": A mixed methods pilot study of young adults attending a wilderness camp. Evidence-Based Complementary and Alternative Medicine, 2015, 1-14. https://doi.org/10.1155/2015/651827

Yavuz, M., \& Tortop, H. (2009, 25-27 Mart). Üstün yetenekli öğrencilerin proje çalışmalarında alan gezisinin ögrenci tutumlarına ve değerler eğitimine etkisi [The effect of field trips on gifted students' project studies on student attitudes and values education] [Sözlü bildiri]. II. Ulusal Türkiye Üstün Yetenekli Çocuklar Kongresi, Eskişehir, Türkiye.

Yıldırım, A., \& Şimşek, H. (2016). Sosyal bilimlerde nitel araştırma yöntemleri [Qualitative research methods in the social sciences] (10. baskı). Seçkin Yayıncılık.

Yin, R. K. (2009). Case study research: Design and methods (4th ed.). Sage. 


\section{Ankara University Faculty of Educational Sciences Journal of Special Education}

2021, 22(3), 725-747
RESEARCH

Recieved Date: 24.08 .20

Accepted Date: 27.01.21

OnlineFirst: 09.02.21

\title{
Gifted Students' Reasons for Participating in Waste Management Themed Nature Education and Post-Training Views*
}

\author{
Özge Ceylan (iD) 1
}

\author{
Zeynep Aslan ${ }^{(1 D 2}$
}

\begin{abstract}
Introduction: Nature education and science camps, which are out-of-school learning environments, offer the opportunity to prepare enriched programs for gifted students. This study supported by Turkey Scientific and Technological Research Council of Turkey (TÜBİTAK), it is aimed to examine the reasons gifted students participate in waste management themed nature education and their opinions about education.

Method: The method of the study is a case study which is one of the qualitative research methods. The study group consists of 29 5th to 6th grade gifted students enrolled in science and art centers (SACs) in Istanbul. Students' views about the project that lasted for 5 days in June 2019 were analyzed using content analysis. The data were collected through the application form and project evaluation form prepared by the researchers, and the diaries were collected from the participants.

Findings: Findings showed that students mostly participated in the project because of their knowledge, development of various skills and love for nature. At the beginning of the project, the students' level of knowledge about waste management was basic and intermediate. Also, they had positive opinions about the project, gained high-level knowledge about waste management, developed thinking skills, reached social and emotional satisfaction, and gained environmental awareness.

Discussion: It was seen findings of previous research are consistent with those in the current study. This research can contribute to the preparation phase of out-of-school education and nature education practices and similar projects for gifted students.
\end{abstract}

Keywords: Waste management, recycling, gifted, nature education, TÜBİTAK.

To cite: Ceylan, Ö., \& Aslan, Z. (2021). Gifted students' reasons for participating in waste management themed nature education and post-training views. Ankara University Faculty of Educational Sciences Journal of Special Education, 22(3), 725-747. https://doi.org/10.21565/ozelegitimdergisi.784925

\footnotetext{
"This study was produced from the "Waste agents in pursuit of transformation" project, which is supported by the code $218 \mathrm{~B} 148$ under the TÜBITAK 4004 school of nature education and science program.

${ }^{1}$ Corresponding Author: Ph.D. student, Y1ld1z Technical University, E-mail: ozgeceylan86@gmail.com, https://orcid.org/00000003-3737-8579

${ }^{2}$ Teacher, Maltepe Kadir Has Science ve Art Center, E-mail: zynpasln2525@gmail.com, https://orcid.org/0000-0001-67477418
} 


\section{Introduction}

When the latest science lesson program of the Ministry of National Education (2018) is examined, it is seen that description of the environment, pollution types, waste types, recycling and reuse, efficient use of resources, local and global environmental problems are mentioned under environmental education. Although various legal and technological preventions are taken to combat environmental problems, they are not sufficient (Erten, 2003). One of the solutions is undoubtedly by raising sensitive individuals who are conscious of nature, and by increasing their awareness and developing a positive attitude. As a result of the ever-increasing needs of the consumer society, with the cumulative increase in environmental damage, the importance of environmental education and environmental problems education for children increases. (Gülersoy et al., 2020). Environmental education should be provided to all individuals, but it would be more appropriate to plan advanced environmental education for gifted individuals who have more curiosity and problem-solving desire in these areas than their peers. Since research on sustainability and environmental issues can be both open-ended and complex, they are ideal study areas for them (Renzulli \& Reis, 2014; Treffinger et al., 2004). Because it will be beneficial to provide these individuals with challenging learning environments that have differentiated and enriched contents and develop their thinking and problem-solving skills. Enriching the teaching environment can be described as a student's work on a subject more deeply and broadly way than others. Enrichment strategies can be defined as individual education, independent study, gradual assignments, research, Saturday and after-school programs, summer programs, mentorship, field trips and projects that develop various creativity (Davis et al., 2014).

Nacaroğlu and Bozdağ (2019) stated that the perceptions of gifted students regarding the consequences and solutions of environmental problems were insufficient, and in this case, these students were not given sufficient environmental education. The perceptions of talented students about environmental problems are important because they show more sensitivity to local and global environmental problems and take an active role in finding solutions to possible problems compared to their peers (Sontay et al., 2014). It is important to bring talented individuals to a level where they can produce the solutions and develop projects, rather than developing interest and attitude in environmental sustainability, waste management, environmental education. Gifted children are usually passionately interested in the world around them and have a keen interest in work involving life issues (Renzulli \& Reis, 2014; Treffinger et al., 2004). In response to their sensitivity to global problems (Piechowski, 1997), it is deemed necessary to increase their awareness of environmental problems with their high-level thinking, problem-solving and producing skills (Mönks et al., 2002). Environmental education, which is only taught theoretically in the classroom environment away from the environment, will cause students not to know their natural environment sufficiently and to approach their environment consciously (Özgel et al., 2018). Supporting the multidimensional development of gifted students depends on the effective and systematic implementation of out-of-school teaching practices (Freeman, 2012; Pfouts \& Schultz, 2003). The descriptions of environmental education in the current curricula, insufficient time for the active participation of the individual in learning, and intensive transfer of information in lessons appear as problems in terms of providing nature education sustainably. For example, while some of the Science and Art Centers (SACs) prepare summer school programs for gifted children, approximately 16,000 students in six gifted research centers in America participate in summer programs that include acceleration and enrichment models (Lee et al., 2008).

\section{Nature Education Program}

In many countries, out-of-school education expenses of students are covered by various sponsors or government institutions, thus allowing out-of-school education practices to emerge (Jeronen \& Jeronen, 2012). In Turkey, lots of projects are carried out with the support of various organizations to remedy the lack of gifted children's environmental education and out of school education one of which is The Scientific and Technological Research Council of Turkey (TÜBİTAK) Science and Society Department.

Enrichment studies for gifted students include content transfer, curriculum narrowing, independent study, field trips and after-school programs. This study contains information about the training program of a project prepared with the support of TÜBITAK. The program of this project is generally formed in the type of after-school and out-of-school enrichment. First of all, the waste management subject in the current curriculum was examined and activities containing information at the upper-class level of students were prepared. Advanced content-oriented activities have been given in various environments through field trips, observations, seminars, questions and answers, and experiments. Some of the activities focused on skills such as creativity, problem-solving skills, and research skills. These activities were carried out through station technique, discussion, problem-solving method, 
and Science, Technology, Engineering and Mathematics (STEM). Besides, activities in which WEB 2.0 tools are used and technology is integrated with the theme of waste are also seen in the program. Students's social skills such as collaborative work, positive attitude towards the environment through drama, group work, creative design studies were also targeted. Also, it was aimed to develop students' social skills such as collaborative work, positive attitude towards the environment through drama, group work, creative design studies. While preparing the content of the program under the main theme of waste management, some points were taken into consideration. For example, basic concepts related to waste and waste management are given up to the 5th grade in the science program. In this program, it started with basic level information about waste management and the project was prepared with upper-class information level content. This information was conveyed by field experts in field trips through seminars, questions and answers and experiments.

In June 2019, a total of 40 hours of practice was carried out for five days with the students. 26 activities were carried out in six different out-of-school environments, including field trips on waste management, problembased learning activities, technological design, artistic activities, experimental activities, mathematics, e-learning, games, collaborative group work. Apart from Kartal SAC, which was the main activity setting, the places the students attended were Ömerli Drinking Water Treatment Plant, Paşaköy Advanced Biological Wastewater Plant, Eyüp İSTAÇ waste storage, recycling, compost facilities, Gebze Technical University Environmental Engineering laboratories, and Pera Museum.

The aim of this study is to determine the reasons for the participation of gifted students in 4004 nature education and science school projects carried out with the support of TÜBİTAK. Also, it is to take the opinions of students about the project program. Accordingly, the general objectives of the project and the consistency or nonoverlapping sides of the students' expectations and achievements from the project were revealed. The study is considered to be original when the sampling feature, waste management theme, application areas and activities of this study are taken together. It is also expected to contribute to the expectations and results of nature education and science school projects, the field of gifted education, out-of-school learning environments and summer camps, waste management and environmental education. Therefore, the following research questions guided the study:

1. Why do gifted students participate in nature education with the theme of waste management?

2. What are the opinions of gifted students about waste management themed nature education practices?

\section{Method}

\section{Research Design}

The design of the study is a case study which is one of the qualitative research methods. Since there is an evaluation of the nature education program applied in this study, a holistic single-case design was used.

\section{Study Group}

The study group of the research was chosen by criterion sampling method, one of the purposeful sampling methods. The criteria used in sample selection were as follows; being enrolled in one of the SAC centers in Istanbul, passing from 5th to 6th grade, not participating in the 4004 projects before and dealing with waste management, which was the subject of the program. The participants consisted of 15 girls and 14 boys, a total of 29 gifted students.

\section{Data Collection Tools and Analysis}

Application form to determine the reasons for students' participation in the project in the research; Participant diary and project evaluation form were used as data collection tools to identify thoughts on implementation. The data were started to be collected with the form used at the application stage. Participants meeting the eligibility criteria were selected and the activity program was implemented for five days. During this period, a participant diary was written for the students. At the end of the fifth day, a project evaluation form was given and students were asked to fill it out. Since the research was planned in 2018 and data were collected in 2019, the ethics committee consent was not obtained. A legal permit was obtained from the national education directorate of the district where the study was conducted.

The analysis of the data was done by the content analysis method. Then the data were encoded separately by two different researchers. Subsequently, themes and categories were developed and edited. The themes and 
categories of the two researchers were compared, and similar ones were reconstructed by reaching a consensus on those that were not taken directly. To ensure the reliability of the study, the categories between the two researchers were calculated with Miles and Huberman's (1994) formula "Reliability = [Agreement / (Disagreement + Agreement)]". As a result, the reliability of the study among researchers was found to be $86 \%$. This value shows that inter-researcher reliability is ensured.

\section{Results}

Regarding to the first research question, the students were asked why they participated in the waste management themed nature education. Findings for the first question were obtained from the analysis of the application form. The reasons for gifted students to participate in the waste management themed nature education are gathered under 26 codes with three themes as knowledge, skills and attitude and seven categories.

Some of the students' reasons for participating were gathered under the "knowledge" theme, and they talked about two types of knowledge, with basic knowledge $(f=8)$ and in-depth knowledge $(f=10)$ codes, depending on the category of acquiring knowledge. Besides, when the students were asked what they knew about waste management, it was seen that their explanations were basic $(f=14)$, intermediate $(f=10)$ and good $(f=5)$. Some of the reasons for students' participation were gathered under the "skill" theme. The skill theme has categories as scientific process skill $(f=5)$, thinking skill $(f=7)$, engineering design skill $(f=4)$ and learning skills $(f=3)$. The students' reasons for participation were finally collected under the theme of "attitude". Two categories were created in the attitude theme: affective dimension $(f=27)$ and behavior dimension $(f=15)$.

The second research question is "What are the opinions of gifted students on waste management themed nature education practices?" in the form. Data were obtained by examining the answers given by the students to the project evaluation form and participant diaries. The opinions of the students who participated in the waste management themed nature education were revealed through diaries and project evaluation forms. Four themes, thirteen categories and 52 codes were created from the data collected from these tools.

The "views on activities" theme has four categories: type $(f=67)$, duration $(f=13)$, number $(f=17)$, and feature $(f=98)$. This theme reflects students' thoughts on program activities. The type category reflects the comments made about the types of activities in the program. The duration category reflects the comments made about the duration of the activities. The number category reflects the comments on the number of activities. The feature category reflects the comments made about the general characteristics of the activities. The "views on the project" theme has four categories: emotion $(f=63)$, sharing $(f=31)$, duration $(f=4)$ and services $(f=16)$. This theme addresses dimensions such as the general structure and execution of the project. The emotion category reflects the feelings towards the whole project. The sharing category reflects who they shared the project with. The duration category reflects ideas about the overall duration of the project. The services category reflects the comments on the services received from the project. The "views on the theme" theme has two categories: waste management $(f=67)$ and environment $(f=55)$. This theme reveals students' views about waste management, which is the theme of the project. While the theme of waste management gathered students' thoughts under the title of waste management in the program; The environment category includes the comments made about the environment. The "view on acquisitions" theme has three categories: new knowledge $(f=71)$, affective acquisition $(f=47)$, social acquisition $(f=10)$. The acquisition theme includes the acquisitions students have acquired during the project. The new knowledge category reflects the types of knowledge students learn from the project. The affective acquisition category reflects the students' affective acquisitions such as attitude, behavior and emotion obtained from the project. The social acquisition category reflects students' comments about their social skills during the project.

\section{Discussion}

In line with the research questions, the data were analyzed and findings were obtained. Findings were grouped under three categories as knowledge, skills and attitude. The general objectives of the project for gifted students were to increase their level of knowledge, to raise awareness about waste management, to enable them to learn while having fun, to examine waste management and recycling areas on-site, to investigate and question waste problems with their gifted peers, and to produce creative solutions. The students stated that they were mostly attended this program to get information about waste management. In addition, the majority of students stated that they loved nature very much and wanted to raise awareness about waste and protect the environment. Moreover, some students wanted to solve environmental problems creatively, produce products and improve their self- 
capacity. In this case, it can be said that the application purposes of the students and the general aims of the project coincide. In such project-based out-of-school education programs, the acquisitions will be more meaningful and permanent if the goals of the participants and the goals of the project coincide. Because at the beginning of the learning process, cognitive and affective preparation is important. Öztürk-Akar and Ayvaz (2018) revealed the reasons for gifted students to participate in a project similar to the program in this study. According to their research, the students stated that they were interested in the subject of the Project and wanted to develop their potential, acquire new information and make new friends. On the other hand, in this study only one of the student stated that he wanted to communicate with his peers like himself. Similar to this finding, Şahin et al. (2019) stated that in their out-of-school science education with 35 gifted students at the high school level, only two of them participated in the project to communicate and collaborate. It is known that gifted students experience socialemotional problems (Sak, 2012). With the finding of this study, it can be said that the students reflect the feeling of being socially alone.

To evaluate the implemented program, participant diaries and project evaluation forms were examined. According to the findings, the answers of the students were categorized into four themes as activities, projects, themes and acquisitions. Evaluating the activities, the students stated that they were satisfied with the trips, experiments and overall. In another study, Ayaydin et al. (2018) stated that the students learned by having fun and the information they learned from the project was permanent. Tortop (2012) reported that students' attitudes towards the environment and their knowledge about energy increased at the end of the program. Çavuş et al. (2013) stated that out-of-school learning environments have an important role in students' gaining environmental awareness and that the number of activities outside of school should be increased. Another finding of this study is that the students stated that the tests used in assessment and evaluation activities were numerous and long-term. It was also observed that the students got bored while doing the tests. The reason for this situation can be interpreted as the increase in the number of tests given to gifted students in SACs in recent years and the frequent exposure of students to such research tests. It is known that measurement and evaluation activities are important in projects. To prevent students from getting bored with measurement activities, researchers may be advised to consider their levels and needs. Again, the students stated that the activities were mostly fun, informative and conscious. The findings reported in many similar studies (Altan et al., 2019; Hırça, 2013; Öztürk-Akar \& Ayvaz, 2018; Öztürk et al., 2020; Su, 2019). In addition to positive opinions, there are comments such as boring, tiring and irrelevant. Although such comments are few, some of the students are bored with the activities; some are tired due to the busy schedule that starts in the morning and ends in the evening; others said that they could not associate activities with waste management. Considering that the interests and abilities of the students are different, it comes to mind that not every method can attract their attention. At this point, different educational interventions can be made for bored students. To reduce the intensity of the program, the number of days can be increased or the number of activities can be decreased. The positive findings of the general comments about the project are mostly the likes of the project, the sharing of the project with the family, the love of the application areas and the satisfaction about the meals. Sharing the project with family or friends contributes to the dissemination of information about waste management, the promotion of TÜBITAK and the development of positive thinking. Also, the intensity of families' interest in the project can be related to their demographic structure, that is, their education level is usually undergraduate and above. The finding that can be expressed as negative comments or suggestions is that the number of days of the project is more. The free project is another feature expressed by the students. Although the importance of providing environmental education to students is known, some sources state that many children do not have the opportunity to take this course (Spellman \& Stoudt, 2013). It is known that such projects create equal opportunities among students, and the value of the project increases especially when it is aimed at teaching disadvantaged individuals (e.g., low socio-economic status, needing special education, difficulty in accessing activities, etc.). For this reason, most state school students $(f=19)$ were selected for this project.

In the waste management category, the concepts related to the theme were determined in line with the answers from the students. In general, it was stated that there are many experiences with information, feelings, attitudes and behaviors about waste management and environmental theme. It shows that the objectives of the project have been achieved with the results such as obtaining information, awareness, contribution to home and country economy. Gaining new knowledge is among the acquisitions of the students from the project. It was observed that they learned many advanced concepts from their peers on waste management and environmental education, increased their awareness and came to the stage of generating solutions for waste problems. In similar studies, nature camps, science or summer schools contribute greatly to the environmental awareness and environmental attitudes of individuals of all ages (Akbaşl1, 2018; Keleş et al., 2010); increased students' interest 
in science and scientific studies (Akay, 2013); and it is stated that students increase their environmental awareness and awareness of environmental pollution (Avc1 et al., 2015; Feyzioğlu et al., 2012; Ugulu, 2019).

As a result, it was observed that the nature education program, which was attended by gifted students in line with their wishes, interests and curiosities, contributed to their acquisition of high-level knowledge, development of thinking skills, social and emotional satisfaction, and awareness of the environment. Considering their abilities, it is important to educate them about waste management, which is one of the important environmental problems of the future, and that they can use their potential to solve these problems. Moreover, nature education at an early age will be the first step that starts with making them aware of environmental problems and gain sensitivity.

\section{Limitations and Recommendations}

The research is limited to Istanbul province, 29 gifted students, the theme of waste management, 26 activities lasting 40 hours and the data collection tools used. In this direction, the following suggestions can be made to researchers who will work on nature education for gifted students;

Waste management should be included in education programs in detail and various recycling campaigns should be organized in schools.

1. Project duration may be longer than a week. The request of the students in this project is in the same direction.

2. Projects for all students, including gifted students, should focus on developing higher-order thinking skills, 21st century skills and problem-solving skills.

3. A project with a similar theme can be applied to younger gifted students to raise early awareness and sensitivity.

4. Considering that students apply to the training in line with their interests, project proposals can be prepared not only on the theme of environmental education or waste management but also on specific topics from many different fields.

5. Teachers can prepare enriched or differentiated activities and programs based on environmental problems to meet the environmental education needs of gifted students sufficiently.

6. Out-of-school teaching methods should be included more in annual plans.

\section{Author's Contributions}

Özge CEYLAN is the coordinator of the supported project. At the same time, it is the researcher who determines the subject of the research, collects data, analyzes data and makes the majority of reporting. Zeynep ASLAN is the trainer in the project. She performed the task of collecting data, helping to analyze data and writing a part of the report.

\section{Acknowledgment}

We would like to express our gratitude to TÜBİTAK, which provided financial resource for our research, and Kartal Science and Art Center for their in-kind support in the realization of the project. 